\title{
Genetic analysis of male Hungarian Conquerors: European and Asian paternal lineages of the conquering Hungarian tribes
}

\author{
Erzsébet Fóthi $^{1}$ (1) $\cdot$ Angéla Gonzalez ${ }^{2} \cdot$ Tibor Fehér $^{3} \cdot$ Ariana Gugora $^{4} \cdot$ Ábel Fóthi $^{5} \cdot$ Orsolya Biró $^{6} \cdot$ Christine Keyser $^{2,7}$
}

Received: 11 March 2019 / Accepted: 16 October 2019 / Published online: 14 January 2020

(C) The Author(s) 2020

\begin{abstract}
According to historical sources, ancient Hungarians were made up of seven allied tribes and the fragmented tribes that split off from the Khazars, and they arrived from the Eastern European steppes to conquer the Carpathian Basin at the end of the ninth century AD. Differentiating between the tribes is not possible based on archaeology or history, because the Hungarian Conqueror artifacts show uniformity in attire, weaponry, and warcraft. We used Y-STR and SNP analyses on male Hungarian Conqueror remains to determine the genetic source, composition of tribes, and kin of ancient Hungarians. The 19 male individuals paternally belong to 16 independent haplotypes and 7 haplogroups (C2, G2a, I2, J1, N3a, R1a, and R1b). The presence of the N3a haplogroup is interesting because it rarely appears among modern Hungarians (unlike in other Finno-Ugric-speaking peoples) but was found in $37.5 \%$ of the Hungarian Conquerors. This suggests that a part of the ancient Hungarians was of Ugric descent and that a significant portion spoke Hungarian. We compared our results with public databases and discovered that the Hungarian Conquerors originated from three distant territories of the Eurasian steppes, where different ethnicities joined them: Lake BaikalAltai Mountains (Huns/Turkic peoples), Western Siberia-Southern Urals (Finno-Ugric peoples), and the Black Sea-Northern Caucasus (Caucasian and Eastern European peoples). As such, the ancient Hungarians conquered their homeland as an alliance of tribes, and they were the genetic relatives of Asiatic Huns, Finno-Ugric peoples, Caucasian peoples, and Slavs from the Eastern European steppes.
\end{abstract}

Keywords aDNA $\cdot$ Y-STRs and SNPs $\cdot$ Paternal lineages $\cdot$ Ancient Hungarians

\section{Introduction}

According to the general belief, the Finno-Ugric-speaking Hungarians left Magna Hungaria, their original homeland in the Western Ural Mountains (i.e., present-day Bashkortostan), for Levedia, on the edge of the Khazar Khaganate, and then moved to Etelköz, an area between the Don and Danube

Electronic supplementary material The online version of this article (https://doi.org/10.1007/s12520-019-00996-0) contains supplementary material, which is available to authorized users.

Erzsébet Fóthi

fothi.erzsebet@nhmus.hu

1 Hungarian Natural History Museum, Ludovika tér 2, Budapest 1083, Hungary

2 Institute of Forensic Medicine, University of Strasbourg, 11 rue Humann, 67085 Strasbourg Cedex, France

3 The Hungarian Magyar Family Tree DNA Project, Budapest, Hungary
Rivers. They conquered their current homeland in the Carpathian Basin in $895 \mathrm{CE}$ and defeated the Moravian Kingdom led by Svatopluk in 902 CE (see Fig. 1).

The nomadic ancient Hungarians from the Eastern European steppes consisted of an alliance of seven tribes, which was joined by the Kabars that had splintered off from the Khazars. At the end of the ninth century CE, following
4 Institute for Geological and Geochemical Research, Hungarian Academy of Sciences, Budaörsi út 45, Budapest 1112, Hungary

5 Institute of Enzymology, Research Centre for Natural Sciences, Hungarian Academy of Sciences, Magyar tudósok körútja 2, Budapest 1117, Hungary

6 Department of Obstetrics and Gynaecology, Semmelweis University, Baross utca 27, Budapest 1088, Hungary

7 CNRS, FRE 2029 - BABEL, Descartes University of Paris, Paris, France 


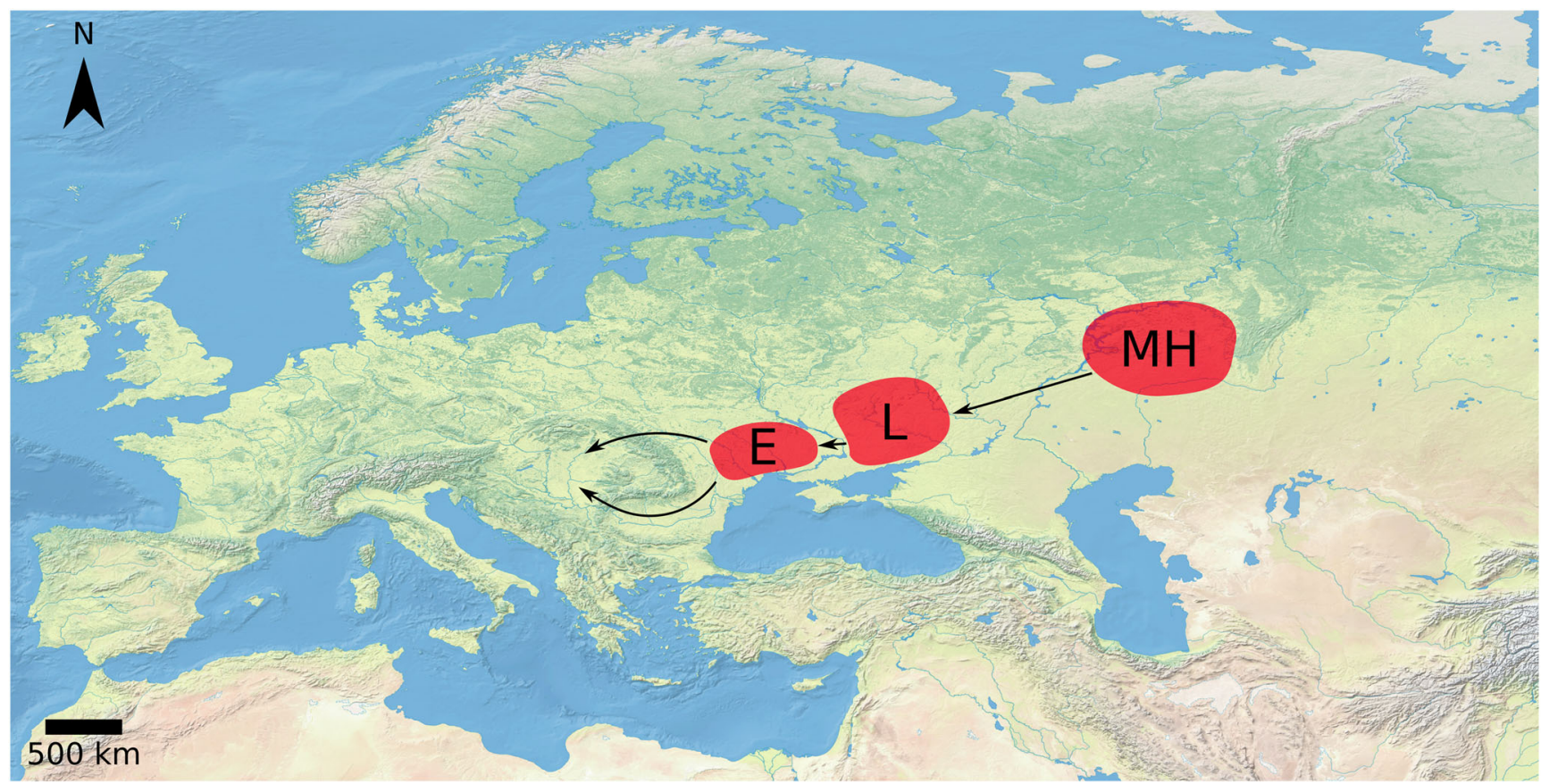

Fig. 1 The putative migration route of the ancient Hungarians. MH: Magna Hungaria, L: Levedia, E: Etelköz

confrontations with the Turkic Pechenegs, Árpád led the tribes out of Etelköz to the Hungarians' current home in the Carpathian Basin.

Linguists agree that the Hungarian language is essentially Finno-Ugric, but it was also influenced by Iranian, Turkic, and Slavic languages. As a result, the currently accepted view among researchers is that the Hungarian Conquerors spoke a Finno-Ugric language but looked and lived like Turkic peoples (Róna-Tas 1995; Bálint 2006). The term "Hungarian Conquerors" is well-known and is traditionally applied in Hungarian scientific life from history to archaeology and anthropology, and is widely used in the field of archaeogenetics (Tömöry et al. 2007; Csányi et al. 2008; Csősz et al. 2016; Neparáczki et al. 2017, 2018). See Online Resource 1 (ESM_1) for more information on the origin stories, history, linguistics, and archaeology of the ancient Hungarians.

Although several thousand Hungarian Conqueror graves have been discovered, containing rich skeletal and artifact assemblages, the origin of the ancient Hungarians has remained unclarified. Early anthropological research placed the ancient Hungarian homeland in the Volga-Kama region (Lipták 1983). Tóth (1981) and Éry (1983) theorized that the classic Hungarian Conquerors came from farther east and they placed the origin of most Asian elements of the Hungarian tribes in the Khazak steppes. Based on Fóthi's (2014) interpretation, the Hungarian Conquerors had ties to the Northern Pontus and Volga-Kama regions during the migration period; however, the closest anthropological parallels were found among the Central Asian and Southern Siberian nomadic Turkic tribes from the 5 th-7th centuries CE.
The results of the first genetic tests increased the number of answerable questions. Based on analyses using classical markers, the modern Hungarian population is very similar to other European populations, especially Slavic- and Germanicspeaking ones, while the frequency of genetic variants typical around the Ural Mountains is only 13\% (Guglielmino et al. 2000). Mitochondrial DNA population tests yielded similar results; the majority of the maternal genetic lineages were identical to those of the surrounding European peoples (Lahermo et al. 2004; Semino et al. 2000). The first archaic mtDNA analyses also supported this finding (Tömöry et al. 2007).

Tambets et al. (2018) studied the autosomal genetic variation of Uralic-speaking populations and found that the recent gene pool of Hungarians did not form genetic clusters with other Uralic speakers but instead grouped with a wide range of geographically adjacent samples.

Recent studies have dedicated greater attention to the socalled classic Hungarian Conqueror samples contrary to previous, random testing, which mostly included remains from the tenth century CE commoner cemeteries. A new archaic mtDNA analysis (Csősz et al. 2016) suggests that both Finno-Ugric roots and Central Asian Turkic influxes were possible genetic influences on the conquerors' mixed genetic composition. Neparáczki et al. (2018) suggested that at least one-third of the Hungarian Conquerors' maternal lineage is descended from Central-Inner Asia, most likely from the Asiatic Huns.

Genetic testing of the modern Hungarian populations' paternal lineage showed either no or very low frequency of the 
Y-chromosomal N-Tat haplogroup (Zerjal et al. 1997; Semino et al. 2000; Csányi et al. 2008; Fehér et al. 2015; Pamjav et al. 2017), which is dominant in all the other Finno-Ugric populations (Zerjal et al. 1997). On the other hand, it is noteworthy that in one study, the N-Tat (M46) Y-chromosomal marker was found in $50 \%$ of the investigated tenth century CE classic Hungarian Conquerors (Csányi et al. 2008).

However, a recent study by Post et al. (2019) confirmed that a small number of N3a4-Z1936 lineages are shared not only by Hungarians and Mansi but also by the other Ob-Ugric group, Khanty. The exclusivity of this Ugric connection is that it is missing from other European populations and its nonUgric appearance is restricted to the Volga-Ural region, notably Bashkirs and Tatars, corresponding to the territory of "Magna Hungaria" where proto-Magyars lived before the conquest of the Hungarian Basin and where Friar Julian found a surviving Hungarian-speaking group in the thirteenth century before the Mongol raids (Vásáry 2015).

It is known that many nomadic tribes practiced (and still practice) patrilocal exogamy, in which the male members choose wives from other tribes. In that context, to study the genetic makeup of nomadic tribes, the analysis of maternal lineages is less meaningful than the paternal ones. For this reason, we conducted Y-chromosomal DNA analysis to determine the genetic origins of the Hungarian Conquerors. The purposes of the present study were (i) to determine the genetic makeup of the Hungarian Conquerors, (ii) to find out if there were any ancestral differences among the Hungarian Conqueror components, and (iii) to investigate whether the single Uralic homeland hypothesis stands, or other geographical regions might have played a role as a genetic source for some Hungarian tribes.

\section{Materials and methods}

\section{Samples}

Nomadic peoples traditionally determine tribal descent patrilineally; therefore, we focused on the remains of classical Hungarian Conqueror males. Our aim was to examine the first generation of Hungarian Conquerors and to exclude the integrated local individuals from the test samples. For that reason, we aimed at choosing the graves containing artifacts most characteristic of the Hungarian Conquerors (see Online Resource 2; ESM_2). The majority of the research sample is from the Upper Tisza region (14/19), as this is where the Hungarians founded their first royal seat in the first half of the tenth century CE (Révész 1996). A smaller proportion of samples came from the Central Tisza region (5/19), which was a regional center in the tenth century CE (Madaras 2014) (Fig. 2).

Anthropological information about the studied graves, as well as the sample codes, are listed in Table 1.

\section{Sample preparation and DNA extraction}

DNA extraction was completed on well-preserved tooth and bone (os petrosum) samples from 24 males archived in the Department of Anthropology at the Hungarian Natural History Museum in Budapest. Sufficient quality and quantity of DNA could be obtained from the samples of 19 ancient individuals to run STR analysis. As such, we were able to determine the haplogroups of 19 samples.

Y-chromosomal STR and SNP analyses were performed in the ancient DNA lab of the Institute of Forensic Medicine, University of Strasbourg. For each individual tested (apart from $\mathrm{RP} / 1$ where only petrous bones were available), tooth and petrous bone sample were used for the genetic analyses. To prevent any external contamination, the teeth were first decontaminated with bleach, and then rinsed with ultrapure water, exposed to UV light $(254 \mathrm{~nm})$ on each side for $30 \mathrm{~min}$, and powdered in a grinder mill under liquid nitrogen (6870 SamplePrep Freezer Mill $\AA$, Fisher Bioblock). The periosteum of the petrous bones was mechanically removed with a sterilized Dremel $\AA$ under a fume hood, dried, rinsed, and exposed to UV radiation. The dense bone of the otic capsule was collected through low-speed drilling. The fine powder was recovered into a small plastic cup.

Two hundred fifty milligrams of tooth or petrous bone powder was used to extract DNA, as described in Mendisco et al. (2011).

\section{Y-chromosomal analysis}

Twenty-seven Y-chromosomal STRs (DYS19, DYS385a/b, DYS387S1a/b, DYS389I, DYS389II, DYS390, DYS391, DYS392, DYS393, DYS437, DYS438, DYS439, DYS448, DYS449, DYS456, DYS458, DYS460, DYS481, DYS518, DYS533, DYS570, DYS576, DYS627, DYS635 (Y GATA C4), and Y GATA H4) were amplified using the Yfiler( Plus PCR Amplification kit (Thermo FisherScientific) from the two types of DNA extract. Experimental conditions followed those recommended by the manufacturer, except that 30 cycles were used instead of 27. Capillary electrophoresis was run on the ABI 3500 Genetic Analyzer (Thermo Fisher Scientific), and data analysis was performed with the GeneMapper ${ }^{\mathrm{TM}} 4.1$ software (Thermo Fisher Scientific).

Seven SNPs (N-L1034, N-VL29, R-Z93, R-M558, J-P58, JL620 and J-FGC6064) were also genotyped. These SNPs were amplified with the following thermal cycling conditions: a first, denaturation step at $95{ }^{\circ} \mathrm{C}$ for $3 \mathrm{~min}$; followed by 38 cycles of denaturation at $95{ }^{\circ} \mathrm{C}$ for $45 \mathrm{~s}$; annealing at $55^{\circ} \mathrm{C}$ for $60 \mathrm{~s}$; and extension at $72{ }^{\circ} \mathrm{C}$ for $60 \mathrm{~s}$, with a final extension step at $72{ }^{\circ} \mathrm{C}$ for $10 \mathrm{~min}$. PCR products were sequenced using BigDye Terminator Cycle Sequencing kit, version 1.1 (Thermo Fisher Scientific), according to the manufacturer's recommendations. Sequencing products were then purified by ethanol precipitation and finally subjected to capillary electrophoresis on ABI 


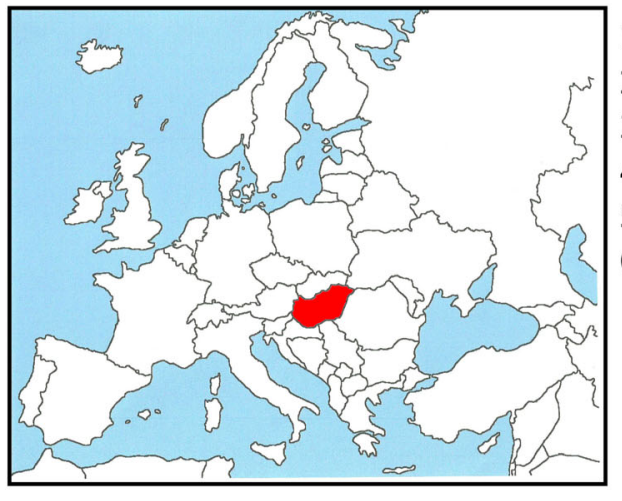

1 Bodrogszerdahely-Bálványdomb

2 Karos-Eperjesszög I.

3 Karos-Eperjesszög II.

4 Karos-Eperjesszög III.

5 Nagykőrös-Fekete dűlő

6 Nagykörü-Május 1. úti bölcsőde
7 Örménykút 52. lelőhely

8 Rakamaz-Túróczi part

9 Rétközberencs-Paromdomb

10 Tiszaeszlár-Bashalom

11 Tiszakécske-Ókécske

12 Tuzsér-Boszorkányhegy

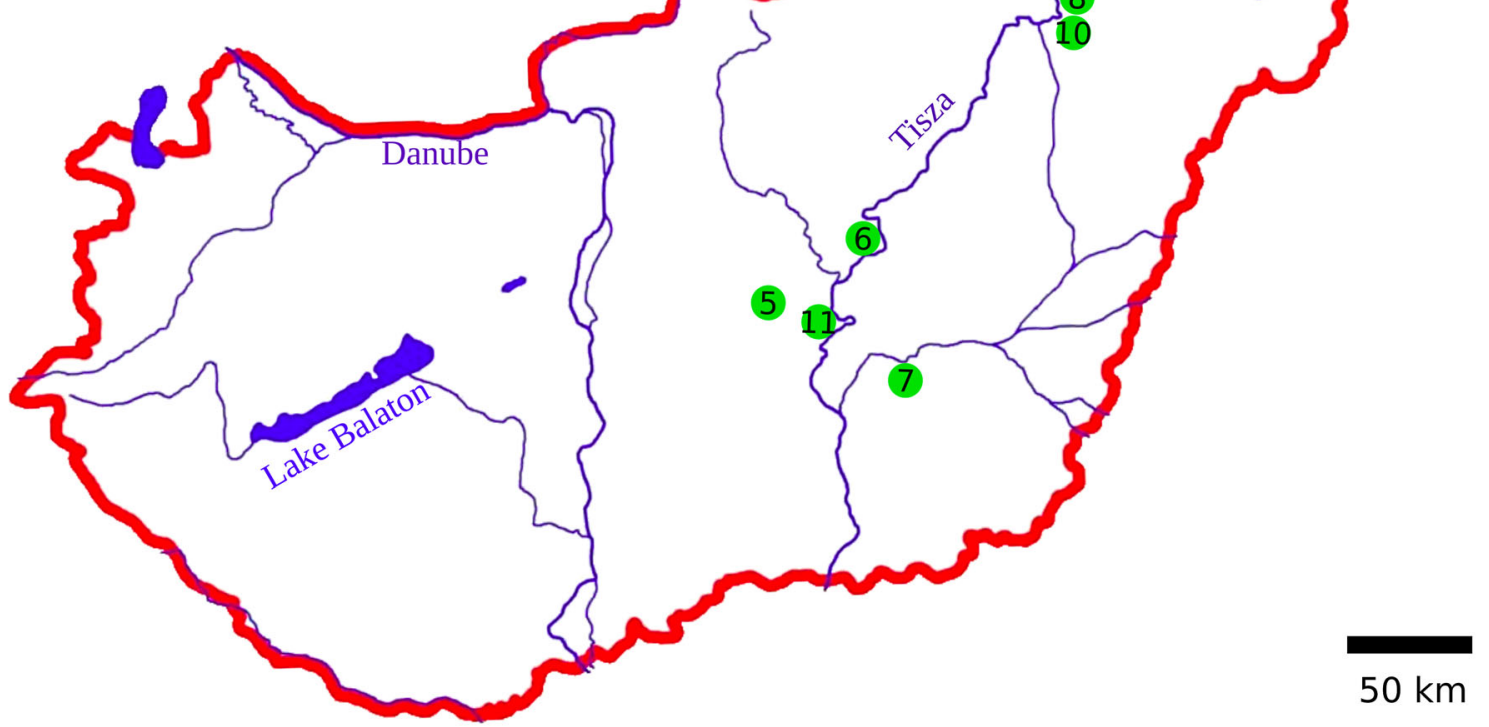

Fig. 2 Geographical distribution in Hungary of the research samples. We included individuals belonging to the first or second generation of Hungarian Conquerors (first half of the tenth century CE) in our research sample. See Online Resource 3 (ESM 3) for additional site information

3500 Genetic Analyzer (Thermo Fisher Scientific). The resulting sequences were assembled and edited using the software Sequencher, version 5.1 (Gene Codes). The SNP NZ1936 was typed by Neparáczki et al. (2019) at the Department of Genetics, University of Szeged.

Multiple independent DNA extractions and PCR amplifications were carried out for each sample. In order to control for possible modern contamination, the DNA extracted from saliva samples of all people handling the material or working in the laboratory was genetically typed and then compared with the profiles or haplotypes of all ancient samples.

\section{Phylogenetic study}

Y-haplogroups of the samples were determined from the available STR data with the NEVGEN predictor. ${ }^{1}$ In many cases, subgroups further downstream were predicted from medianjoining network analysis, where clear STR variance made it

\footnotetext{
${ }^{1} \mathrm{http}: / /$ www.nevgen.org
}

possible (see below for specific samples). In the cases where multiple subgroups had very similar STR features, targeted SNP tests were carried out to clarify the classification (e.g., in the case of R1a-Z93 vs. R1a-Z280 and under N3a4-Z1936 for the status of L1034).

To examine the STR variation within the sub-haplogroups, median-joining networks were constructed using the Network 5.0.0.0 program (Bandelt et al. 1999). Repeats of the DYS389I locus were subtracted from the DYS389II locus. To put the results into a more extensive geographical context, we included haplotypes of 17 overlapping loci from other populations (the source of populations is indicated below each network, various populations were included according to their relevance for a given haplogroup). Within the network program, the rho statistic was used to estimate the time to the most recent common ancestor (TMRCA) of haplotypes within the compared haplogroups (Bandelt et al. 1999). We used the pedigree rate $2.5 \times 10-3$, as described by Goedbloed et al. (2009), for 17 loci included in the YFilter kit (Applied Biosystem, Foster City, CA, USA). Due to the expansion of Full Genomic testing, an SNP count-based TMRCA estimation method was also used and proved to be 
Table 1 Anthropological description and sample codes of the studied graves

\begin{tabular}{|c|c|c|c|}
\hline Samples & Sample code & Biological profile & Reference \\
\hline Bodrogszerdahely-Bálványhegy/grave 3 & BB3 & adultus male & Malán (1956) \\
\hline Karos-Eperjesszög I/grave 3 & $\mathrm{KEI} / 3$ & maturus male & Kustár (1996) \\
\hline Karos-Eperjesszög II/grave 14 & $\mathrm{KEII} / 14$ & maturus-senilis male & Kustár (1996) \\
\hline Karos-Eperjesszög II/grave 16 & KEII/16 & juvenilis male & Kustár (1996) \\
\hline Karos-Eperjesszög II/grave 29 & $\mathrm{KEII} / 29$ & adultus male & Kustár (1996) \\
\hline Karos-Eperjesszög II/grave 52 & $\mathrm{KEII} / 52$ & maturus male & Kustár (1996) \\
\hline Karos-Eperjesszög II/grave 60 & $\mathrm{KEII} / 60$ & senilis male & Kustár (1996) \\
\hline Karos-Eperjesszög II/grave 61 & KEII/61 & senilis male & Kustár (1996) \\
\hline Karos-Eperjesszög III/grave 11 & KEIII/11 & maturus male & Kustár (1996) \\
\hline Nagykőrös-Fekete dülö/grave 1 & $\mathrm{NF} / 1$ & adultus male & Lipták (1952) \\
\hline Nagykőrös-Fekete dűlő/rave 2 & $\mathrm{NF} / 2$ & maturus male & Lipták (1952) \\
\hline Nagykörü-Május 1. úti bölcsőde/grave 6 & $\mathrm{NM} / 6$ & maturus male & Fóthi unpublished \\
\hline Örménykút-52/Obj. 50 & Ö52/50 & adultus male & Fóthi unpublished \\
\hline Rakamaz-Túróczi part/grave 7 & $\mathrm{RT} / 7$ & maturus male & Éry (1977) \\
\hline Rétközberencs-Paromdomb/grave 1 & $\mathrm{RP} / 1$ & adultus male & Éry (1977) \\
\hline Rétközberencs-Paromdomb/grave 2 & $\mathrm{RP} / 2$ & maturus male & Éry (1977) \\
\hline Tiszaeszlár-Bashalom/grave 13 & $\mathrm{TBa} / 13$ & senilis male & Éry (1977) \\
\hline Tiszakécske-Ókécske/grave 1 & TÓ/1 & maturus male & Lipták (1957) \\
\hline Tuzsér-Boszorkányhegy/grave 6 & $\mathrm{TBo} / 6$ & maturus male & Éry (1977) \\
\hline
\end{tabular}

effective on closely related, as well as genetically distant individuals (Hallast et al. 2015; Underhill et al. 2015). In these recent studies, the pedigree rate based on large number STR loci (Goedbloed et al. 2009) tended to be significantly closer to the SNP-based time estimates. SNP-based mutation rates are reported from the YFull database. ${ }^{2}$

\section{Genetic distance calculations}

$F_{\text {ST }}$ genetic distances and associated $p$ values were calculated from Y-SNP haplogroup frequencies using Arlequin 3.5 software (Excoffier and Lischer 2010). Based on pairwise distances, Kruskal's non-metric multidimensional scaling (NMDS) plots were constructed with the isoMDS $($ ) function from the R package 'MASS' (ver. 7.3-45) (Venables and Ripley 2002). $p$ values were used to distinguish between significant $(p<0.05)$ and nonsignificant distances $(p>=0.05)$, as well as to interpret the distance-based NMDS plot. In the case of non-significant distances between two groups, we rejected the null hypothesis that they had statistically different Y-SNP haplogroup frequencies. We interpreted them as statistically non-separable groups.

\section{Results}

\section{Haplotype analysis of the remains}

Y-haplogroups of the samples were predicted from the generated STR data (see Online Resource 4; ESM_4). The haplogroup predictions and SNP test results are listed in Table 2. Using STR analysis, we were able to determine 16

\footnotetext{
${ }^{2}$ https://www.yfull.com/tree/
}

separate paternal haplotypes from 19 cases of the study population, which haplotypes are not closely related to each other.

The Hungarian Conqueror samples were very heterogeneous in their haplotype distribution (see Fig. 3). The 19 individuals belonged to 16 haplotypes: C2-M217 (1 case, 1 haplotype), G2a (4 cases, 3 haplotypes), I2a (3 cases, 2 haplotype), J1 (1 case, 1 haplotype), N3a (7 cases, 6 haplotypes), R1a-Z93 (2 cases, 2 haplotypes), R1b-L23, and Z2106 (1 case, 1 haplotype).

Similarly, diverse results were generated regarding the haplogroup distribution. There were seven different haplogroups present among the 19 samples: C2-M217 (one sample), G2a (4), I2a (3), J1 (1), N3a (7), R1a-Z93 (2), R1bL23 (1). The analyses also yielded the two branches of the G2a haplogroup (G2a1-U1, L1266; G2a2-P18, L293) and of the N3a haplogroup (N3a2-M2118 and N3a4-Z1936).

\section{Analysis of the remains by haplogroups}

\section{Karos-Eperjesszög II, grave 60 (KEII/60): C2-M217 group, M86 and L1370 subgroup}

This sample belongs to the East Asian C2-M217 group (often called C3 in previous publications), which is frequent among Mongolian Tungusic-speaking peoples (Tambets et al. 2004; Zhong et al. 2010; Duggan et al. 2013). Within the C2-M217 group, the sample belongs to the M48/M86 subgroup, where are two alleles on the DYS19 locus. Modern individuals with the M86 subgroup usually carry the L1370 mutation, estimated to be $2100 \pm 500$ years old. ${ }^{3}$ However, in modern Hungarian-speaking and other European (except Russian)

\footnotetext{
${ }^{3}$ www.yfull.com/tree/C-Y12825
} 
Table 2 Haplogroup analysis of the studied skeleton

\begin{tabular}{|c|c|c|c|}
\hline Sample code & $\begin{array}{l}\text { Y-DNA haplogroup } \\
\text { prediction by NEVGEN }\end{array}$ & $\begin{array}{l}\text { Y-DNA subgroup prediction } \\
\text { based on network analysis }\end{array}$ & Tested SNPs \\
\hline BB3 & N-Tat $100 \%$ & N3a4-Z1936 > Y13850 & L1034- \\
\hline $\mathrm{KEI} / 3$ & G2a1-L293 94.3\% & G2a1-L293 & \\
\hline KEII/14 & N-Tat $100 \%$ & N3a4-Z1936 > Y13850 & L1034- \\
\hline KEII/16 & I2a1b3-L621 100\% & I2-L621 > CTS10228 & \\
\hline KEII/29 & N-Tat $100 \%$ & N3a4-Z1936 > Y13850 & Z1936+', L1034- \\
\hline $\mathrm{KEII} / 52$ & I2a1b3-L621 99.8\% & I2-L621 > CTS10228 & \\
\hline KEII/60 & C2-M217 99.4\% & C2-L1370 > F12970 & \\
\hline KEII/61 & R1a $100 \%$ & R1a-Z93 & Z93+ \\
\hline KEIII/11 & I2a1b3-L621 100\% & I2-L621 > CTS10228 & \\
\hline $\mathrm{NF} / 1$ & J1a3-Z1828 77.9\% & J1-M267 (xL620) & P58-, L620- \\
\hline $\mathrm{NF} / 2$ & R1a $100 \%$ & R1a-Z93 & Z93+, M558-, Z280- \\
\hline $\mathrm{NM} / 6$ & N-Tat $100 \%$ & N3a4-Z1936 > Y13850 & \\
\hline Ö52/50 & N-Tat $100 \%$ & N3a2-M2118 > PH1612 & PH1896- \\
\hline $\mathrm{RT} / 7$ & G2a1-L293 97.9\% & G2a1-L293 & \\
\hline $\mathrm{RP} / 1$ & G2a2b2a1 98.5\% & G2a2-U1 > L1266 & \\
\hline $\mathrm{RP} / 2$ & G2a2b2a1 99.9\% & G2a2-U1 > L1266 & \\
\hline $\mathrm{TBa} / 13$ & R1b $100 \%$ & R1b-L23 > Z2106 & \\
\hline TÓ/1 & N-Tat $100 \%$ & N3a4-Z1936 > Y13850 > L1034 & L1034+ \\
\hline $\mathrm{TBo} / 6$ & N-Tat $100 \%$ & N3a2-M2118 > PH1612 > PH1896 & PH1896+ \\
\hline
\end{tabular}

populations, C-M86 has not yet been found (Zhong et al. 2010; Bíró et al. 2015). We placed the haplotypes of the ancient individuals into a median-joining network with the samples belonging to the C-M86 subgroup $(n=102)$, located on one of the 16 currently known loci (see Fig. 4). Two Family Tree DNA (FTDNA) samples belonging to the M86* (xL1370) subgroup showed up at the edge of the network. Based on STR profile, ${ }^{4}$ the TMRCA of the remaining 100 L1370 samples was determined to be $2242 \pm 577$ years, which corresponds to the estimated SNP-based age and, in both cases, places the common ancestor during the time of the Asian Hunnic (Xiongnu/Hunnu) Empire.

The C-F12970 branch (area $d$ ), to which the Hungarian Conqueror sample belongs, fully matches with one Kazakh and two Altaic Turk (Kizhi) individuals that may be the descendants of the paternal ancestor of the Hungarian Conqueror. Several Mongolian and Uyghur samples are also found on this branch. Based on STR and SNP analyses, F12970 dates to $1739 \pm 606 \mathrm{yBP}$ and $2000 \pm 800 \mathrm{yBP}$, respectively, which is at the end of the Asiatic Hunnic period. Therefore, the Hungarian sample represents a paternal DNA link between the contemporary South Siberian populations and the conquering Hungarians, with the expansion time of the branch coinciding with the Xiongnu period. However,

\footnotetext{
${ }^{4}$ Malyarchuk et al. 2013
}

there is no evidence of this C-F12970 link to South Siberia in modern Hungarian population (Bíró et al. 2015).

\section{Tuzsér-Boszorkányhegy, grave 6 (TBo/6 and Örménykút 52/50 (Ö52/50): N3a2-M2118 (previously called N1c-M2118) group ("Yakut" subgroup), $\mathrm{PH} 1896+$}

These two samples belong to the North Eurasian $\mathrm{N}$ paternal group, N-Tat, which is characteristic of the Yakut people. Subgroup classification based on STR analysis is assured with $100 \%$ certainty due to two rarely mutating markers (DYS392 > 14 and DYS438 = 11). According to Ilumäe et al. (2016), N3a2M2118 appears in 70-90\% of the Central Siberian Turkic

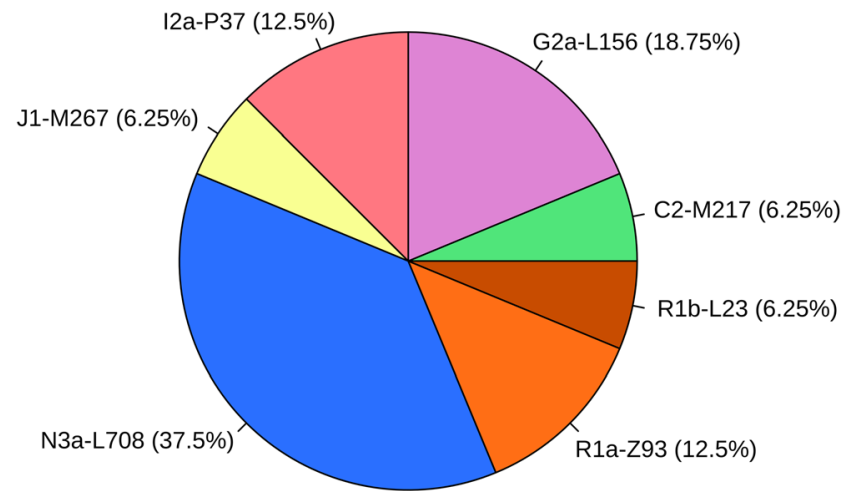

Fig. 3 The frequency of paternal haplogroups in the Hungarian Conqueror samples 


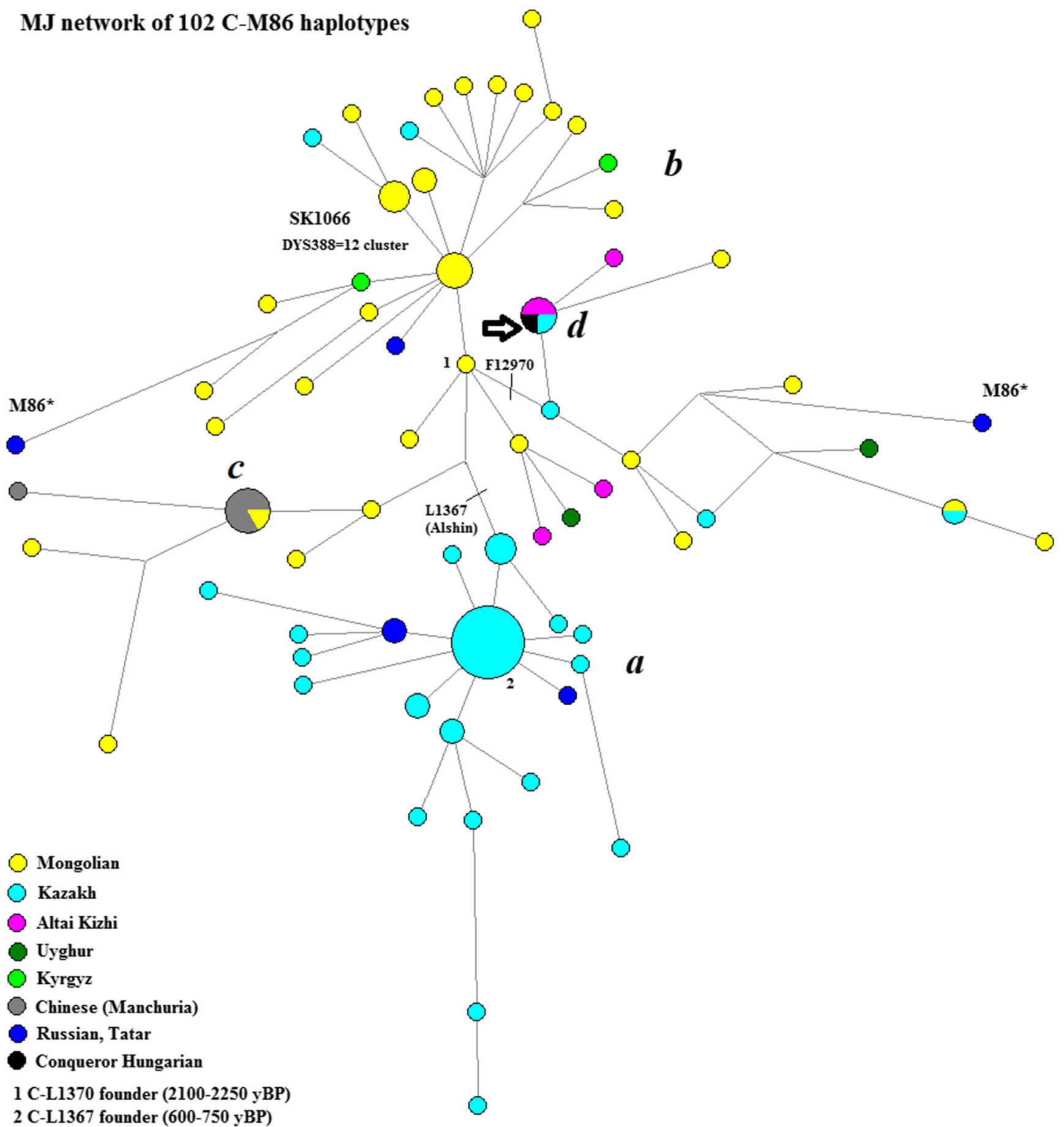

Fig. 4 The network of the C2-M86 haplogroup. The network is divided into four distinct areas: area $a$ (C-L1367 cluster) belongs to the small horde of modern Kazakh; area $b$ belongs to modern Mongols and it is rare in Kyrgyzstan and Kazakhstan (Roewer et al. 2007); area $c$ shows a smaller Mongolian-Manchurian Chinese cluster; area $d$ belongs to the

Yakuts, in $50 \%$ of the neighboring Turkic Dolgans and the Tungusic Evenks, in $10 \%$ of the Khanty, and in $<5 \%$ of other ethnicities. The Hungarian Conqueror samples with the N-Tat group (one of which is also from Örménykút) examined by Csányi et al. (2008) fall into the same subgroup.
Hungarian Conqueror sample, fully matches with one Kazakh and two Altaic Turk (Kizhi) individuals. Source of haplotypes: Malyarchuk et al. (2013); FTDNA C-M217 project (https://www.familytreedna.com/ groups/c3/about/background)

Tuzsér-Boszorkányhegy grave 6 and Örménykút 52/50 are not closely related. We placed both samples in a 10-loci network with the samples from Ilumäe et al. (2016), FTDNA, and a modern N3a2 male from Bodrogköz (Pamjav et al. 2017). In order to determine a more precise age estimate, we created a 
network of Örménykút 52/50 with 14 STR markers, though we only included the figure of 10 loci (see Fig. 5). N3a2's common ancestor, which diverged from the other N-Tat subgroups by $6400 \pm 900$ years, was dated to $3800 \pm 800$ years, based on SNPs.

Cluster $c$ : Based on STR analysis, its age is estimated at $1970-2070 \pm 690$ years, stretching back to the Asiatic Hunnic period. Two Kazakh (Nogai Horde), 1 Anatolian Turk, 1 Lebanese, 1 Volga Tatar, 1 Russian Muslim of indeterminate ethnicity, and 1 Dalmatian Croat sample are included with the 2 Hungarian Conqueror samples. One Lebanese sample tested positive for PH1612 and PH1896 SNPs in Hallast et al.'s (2015) study, while recent testing of living individuals showed that a Hungarian sample from Abaúj county, as well as a Turkish sample from the Hatay region, were also positive for these SNPs. However, the Croatian sample was positive for PH1612 only, not for PH1896. YFull puts the age of PH1612 at 1550 years BP and of PH1896 at 1050 yBP (the time period of the Hungarian conquest). The PH1896 SNP was tested for both bone samples. The Tuzsér sample was positive, while the Örménykút sample was negative for it. The results suggest that these two N3a2 samples represent a link between Hungarian Conquerors and contemporary South Siberian populations with branch expansion time matching Asiatic Hun times, with the Örménykút sample being closer to the contemporary Croatian sample and the Tuzsér sample being a close relative (or possibly an ancestor) of the contemporary Hungarian from Abaúj county.
Karos-Eperjesszög II, graves 14 (KEII/14) and 29 (KEII/29); Bodrogszerdahely-Bálványdomb, grave 3 (BB/3): N3a4-Z1936 (xL1034)

The Karos-Eperjesszög II and BodrogszerdahelyBálványdomb samples are paternal genetic relatives. The samples from Karos grave 29 and Bodrogszerdahely grave 3 have identical genetical markers, while the sample from Karos grave 14 differed in one locus ((DYS389I) and also on DYS635 but that locus was not included into the network. Our Hungarian Conqueror, Mansi, Bodrogköz, and FTDNA data $(n=121)$, along with Ilumäe et al.'s (2016) Z1936 data samples, were included in a 14-loci network (see Fig. 6). Only the Karos grave 29 sample was tested for Z1936 by Neparáczki et al. (2019), but due to Karos grave 14 and Bodrogszerdahely grave 3 have analogous genetic markers, it can be assumed that these belong to the same subgroup.

Post et al. (2019) verified with high-resolution Y chromosome sequencing that the N3a4-B539 subclade links ObUgric Khanty and Mansi with Hungarians as well as Bashkirs and Tatars, and Hungarians form paternal genetic clusters with Bashkirs and Tatars both below B540/L1034 and B545 with an expansion time of 2700-2900 yBP. Thus, these 3 samples $(K E I I / 14, K E I I / 29$, and $B B / 3)$, either representing close relatives or members of the same Hungarian tribe (more distant genetic relatives), might be of Ugric origin from present-day Volga-Ural region. We could not test the samples for SNP Y13850 (B539), but the placement in that clade is clear by STR results.

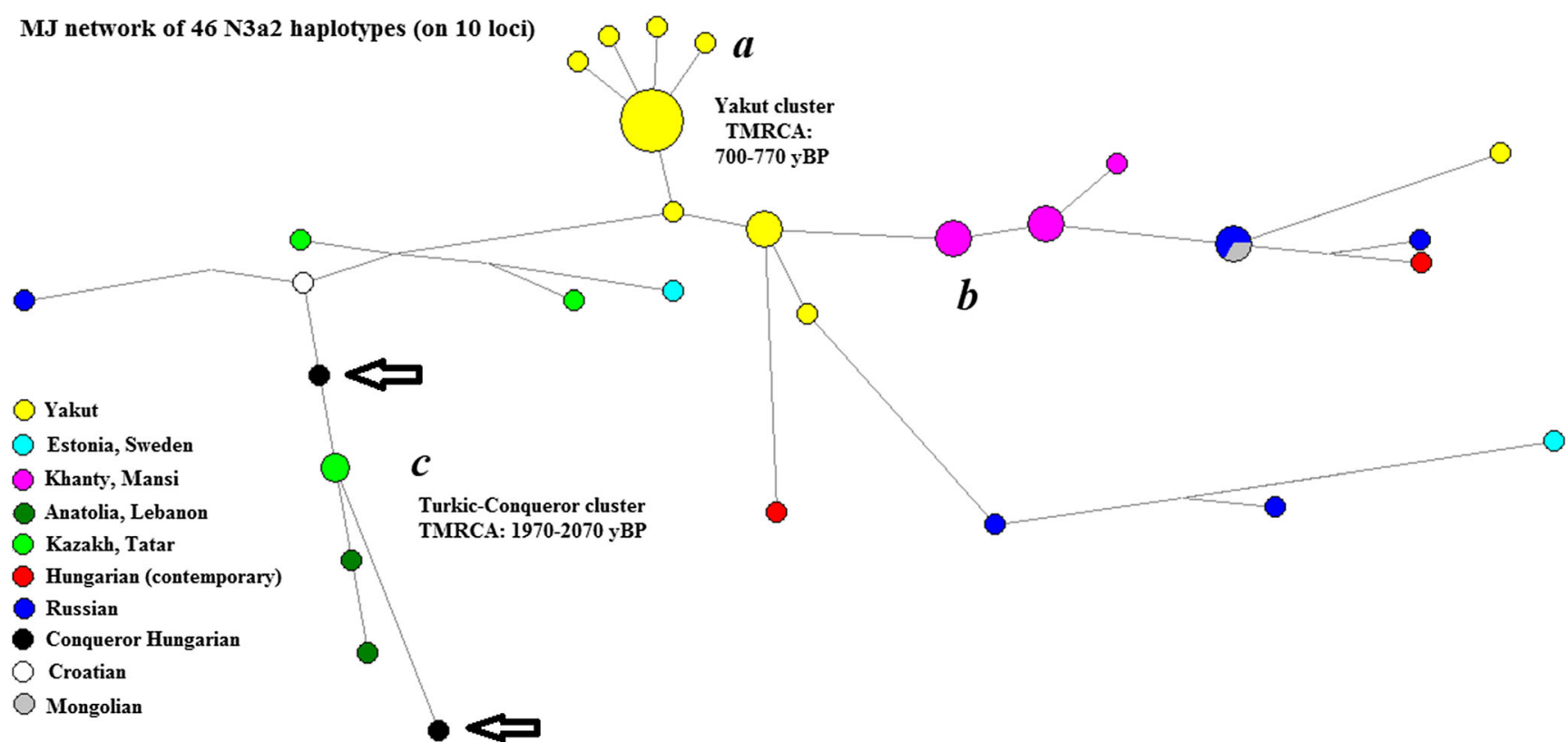

Fig. 5 Network of the N3a2 haplogroup. Three larger clusters are seen on the figure: cluster $a$ belongs to the Yakuts; cluster $b$ belongs to the ObUgric peoples; cluster $c$ includes the 2 Hungarian Conqueror samples.
Source of haplotypes: Ilumäe et al. 2016; Pamjav et al. 2017; FTDNA N North Eurasia project (https://www.familytreedna.com/groups/n-russiadna-project/about/background) 


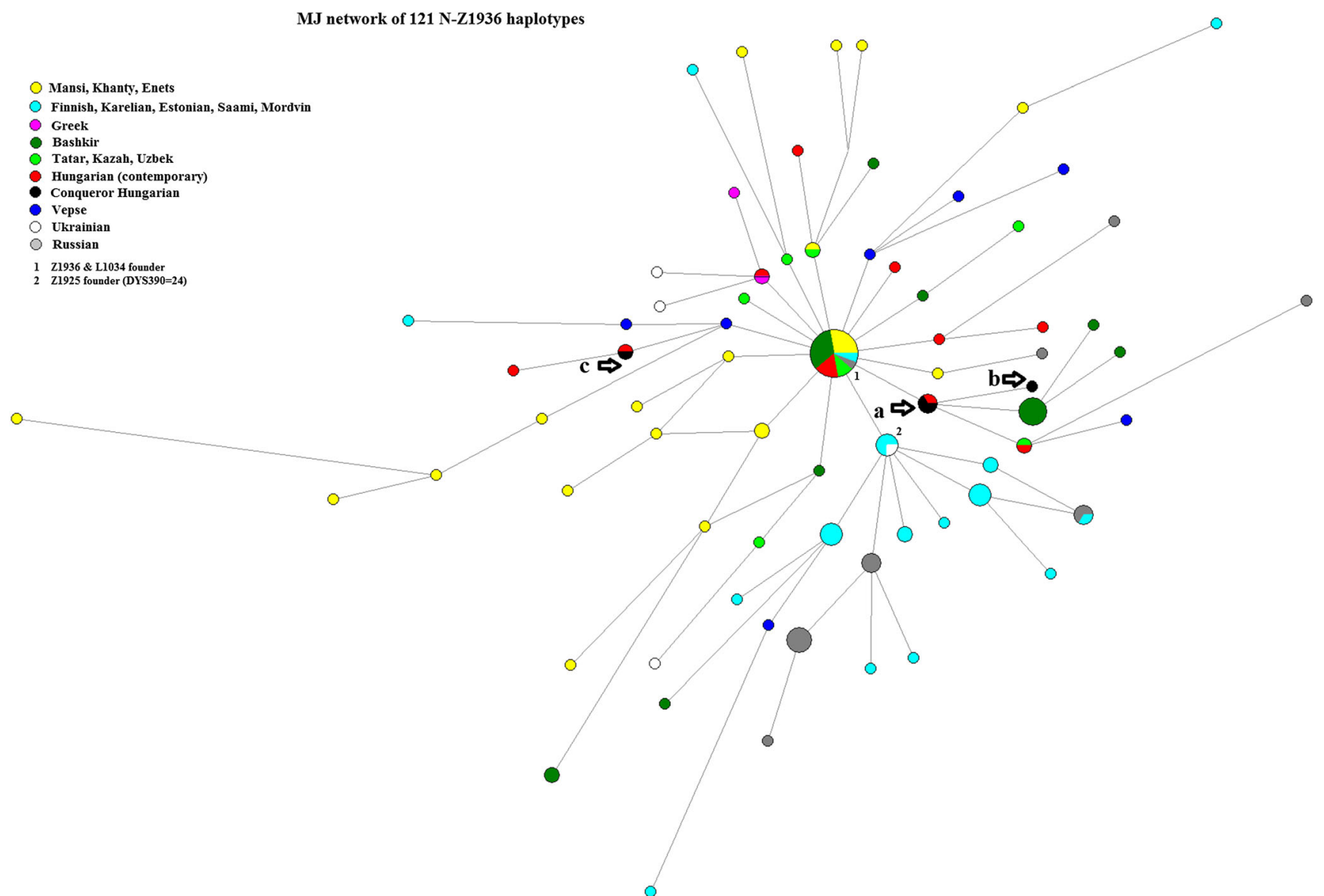

Fig. 6 Network of the N3a4-Z1936 haplogroup. The samples from Karos grave 29 and Bodrogszerdahely grave 3 were a genetic match with a modern Hungarian sample from Szentpéterszeg, Hungary (marked with the arrow $a$ ), while the sample from Karos grave 14 (marked with the arrow $b$ ) differs only on one locus. Additionally, the modern Szentpéterszeg Hungarian sample is 1-1 mutation step from the Z1936/ L1034 founder haplotype (6 Bashkirian, 4 Mansi, 3 Hungarian/Székely, 2

\section{Nagykörü-Május 1. úti bölcsőde, grave 6 (NM/6): N3a4-Z1936 (xL1034), Y13850}

Based on 14 markers, the study sample fully matched to a sample from Mureș County, Romania (Transylvania) in FTDNA's database (see Fig. 6 mark $c$ ), whose SNP tests showed it to belong to the Z1936+Y13850+ L1034group. This group is the ancient relative of the Ugric L1034 group, which is found in modern Volga Tatars from the Republic of Tatarstan. The SNP-based age of its common ancestor with L1034 is $4300 \pm 800$ years, placing the mutations of Y13850 and L1034 around the time of the divergence of the Baltic-Finns (N3a4-B535 branch) from the Ugrians (N3a4-Y13850 branch). This sample shares common paternal ancestors with Ugric-speaking individuals from Western Siberia. The modern Hungarian N3a4Z1936*(xL1034) sample from Bodrogköz (Pamjav et al. 2017) is only one mutation away from the research sample in the Z1936 network.
Tatar, 1 Finnish, 1 Khanty, and 1 Central Russian; marked by 1 on the figure); a modern Bodrogköz Hungarian, which matches a Tatar sample; and a Bashkirian cluster with 6 individuals. NM/6 sample (see below) is marked by $c$ on the figure. Although Vepsians speak a Baltic-Finnic language, they are shown with a separate color due to their genetic difference on DYS390 from the other Baltic-Finns. Source of haplotypes: Ilumäe et al. (2016); Fehér et al. (2015)

\section{Tiszakécske-Ókécske, grave 1 (TÓ/1): N3a4-L1034}

This is the only sample from the analyzed Hungarian Conqueror remains that tested positive for the L1034 group. As such, it connects modern Hungarians and ethnic Székelys with the West Siberian Mansi (Fehér et al. 2015). The sample is genetic one step away (STR difference of 1) from a Greek N3a4-L1034 sample.

\section{Nagykőrös-Fekete dülö, grave 1 (NF/1): J1-M267 (xL620)}

This sample belongs to the J1 subgroup. The J-L136/J-P58 subgroups (11,000-12,000 years old) are characteristic of Semitic peoples (Arabs and Jews) and the so-called Cohen modal haplotype also belongs here. On the other hand, the Z1828 subgroup (8000 years old) is dominant among the peoples of Dagestan in the Northeast Caucasian Mountains. Based on the results from the STR analysis, the Hungarian Conqueror sample belongs neither to the J-L1936/J-P58 nor to the Z1828 subgroup. Its closest 
STR-based genetic relatives are members of a rare subgroup only found in Great Britain, with the L620+ FGC6064+ L136Z1828- mutation. Nevertheless, the Hungarian Conqueror from the Nagykörös-Fekete dülö grave is negative for L620 and P58, while it is very distant from the Z1828 Dagestanian subgroup as well.

\section{Nagykőrös-Fekete dülö, grave 2 (NF/2): R1a-Z93}

We compared 20 loci from this sample with over 4200 37-loci haplotypes in FT DNA's database. We determined that it was 3 genetic steps away from its closest Z93 relatives: 1 South Siberian Khakass, 2 Saudi Arabians, 1 Syrian Arab, 1 German, 1 Pole, 1 Briton, and 1 Iranian (Khorasan Province). In fact, the closest genetic relatives of the study sample belonged to either the Z93* (Z94-) or the Z2125 (common among Iranian and Turkic peoples) group. A Kyrgyz individual from subgroup Z2125 is 1 genetic distance away on 17 markers from the sample published in Underhill et al. (2015). The patrilineal branch of the study sample hails from the Altai-Tian Shan region, of possible Turkic origin.

\section{Karos-Eperjesszög II, grave 61 (KEII/61): R1a-Z93}

We compared 15 loci from this sample with over 4200 37-loci haplotypes from FTDNA's database ${ }^{5}$ and determined that its closest Z93 relatives were 2 genetic steps away. One was an Arabic individual, but the other's origins could not be identified. Both relatives belonged to the $\mathrm{Z} 2125$ subgroup, which is common among Iranian- and Turkic-speaking peoples (Underhill et al. 2015).

Among the 12 loci from the Z93 samples examined by Underhill et al. (2015), several are 1 genetic step away from the Karos-Eperjesszög II sample. Using DYS393 = 13, the sample has 4 full matches (1 Caucasian Mingrelian (Georgian), 1 Iranian, 1 Tajik, and 1 Kyrgyz), while using DYS393=14, it has 5 matches that are 1 genetic step away from the study sample (2 Tajiks, 2 Pashtuns, and 1 Swiss Z93 sample). It is also noteworthy that the sample is 1 genetic step away from a Khazar sample (Klyosov and Faleeva 2017) and that only their DYS385a data differ. Therefore, this sample could be of Turkic/ Khazar origin, as supported by the shared historical connection between the Hungarians of the steppe and the Khazars.

\section{Karos-Eperjesszög II, graves 16 (KEII/16) and 52 (KEII/52); Karos-Eperjesszög III, grave 11 (KEIII/11): I2a1-L621, CTS10228}

The three samples were identical on those loci which were included in the network. One sample was different from the two others on DYS518, but that locus was not included in the

\footnotetext{
5 https:/www.familytreedna.com/public/R1a?iframe=yresults
}

network. Regardless of this single step distance, we can consider the three males close relatives. As the matrilineal lineages (mtDNA X2f) of the individuals from grave 52 in Karos II and grave 11 in Karos III are also identical (Neparáczki et al. 2018), they can be considered full siblings, and the grave goods discovered suggest that this genetic lineage belongs to the chief of the Karos-Eperjesszög settlements. The haplotype of the individual from grave 12 in Karos III (Neparáczki et al. 2017 ) is likewise identical to that of the 3 individuals we examined here, and 11 and was therefore also part of the chief's family. The I2a1-L621 sample from grave 17 in Karos III (Neparáczki et al. 2017), however, was not a close genetic relative, because it differed on several markers.

We looked at 16 loci from 640 I2a-L621 samples in FTDNA's I2a project database and found that 7 individuals were 2 genetic steps away the Karos samples, of whom 1 was a Hungarian from Kunszentmárton, 2 were Ukrainians, 1 was Lithuanian, 1 was Belarusian, 1 was Russian, and 1 was a German from Poland. Based on SNP analysis, the CTS10228 group is $2200 \pm 300$ years old. The group's demographic expansion may have begun in Southeast Poland around that time, as carriers of the oldest subgroup are found there today. The group cannot solely be tied to the Slavs, because the proto-Slavic period was later, around 300500 CE. Furthermore, the A2512 subgroup is typically Mediterranean (Greek, Jewish diaspora). We compared 15 loci from our data with Rębała et al.'s (2013) samples and found that 3 Poles and 2 Slovaks are 1 genetic step away, while 2 other Poles are 2 genetic steps away. The Karos samples' STR data are 1 genetic distance on 17 loci in the Balkans to a Bulgarian from Montana and 2 mutation steps to a Bulgarian from Sofia, a Bulgarian from Plovdiv, and a Tuscan Albanian (see Fig. 7).

As all these hits fit into the time period of the Hungarian Conquest, they may be descendants of the tribes. We determined that the Kunszentmárton Hungarian sample belongs to the A815 subgroup. This is interesting, because this subgroup is also found in Moravia, Slovakia, and Ukraine, and it has a specific North Caucasian Karachay subgroup, as well. ${ }^{6}$

\section{Tiszaeszlár-Bashalom, grave 13 (TBa/13): R1b-L23, Z2106}

This sample belongs to either the Indo-European R1b-M269 subgroup's L23(xM412) haplotype or to the Z2106 subgroup (see Fig. 8), which is commonly referred to as "Eastern European R1b." It is found extensively among Bashkirs (Burzyansky), Armenians, various Northern Caucasian peoples, Albanians, and Greeks but in a less degree among Iranians, Eastern European Slavs, and Hungarians (Myres et al. 2011). This group dominates the skeletal remains that

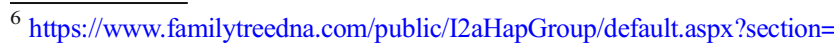
yresults
} 


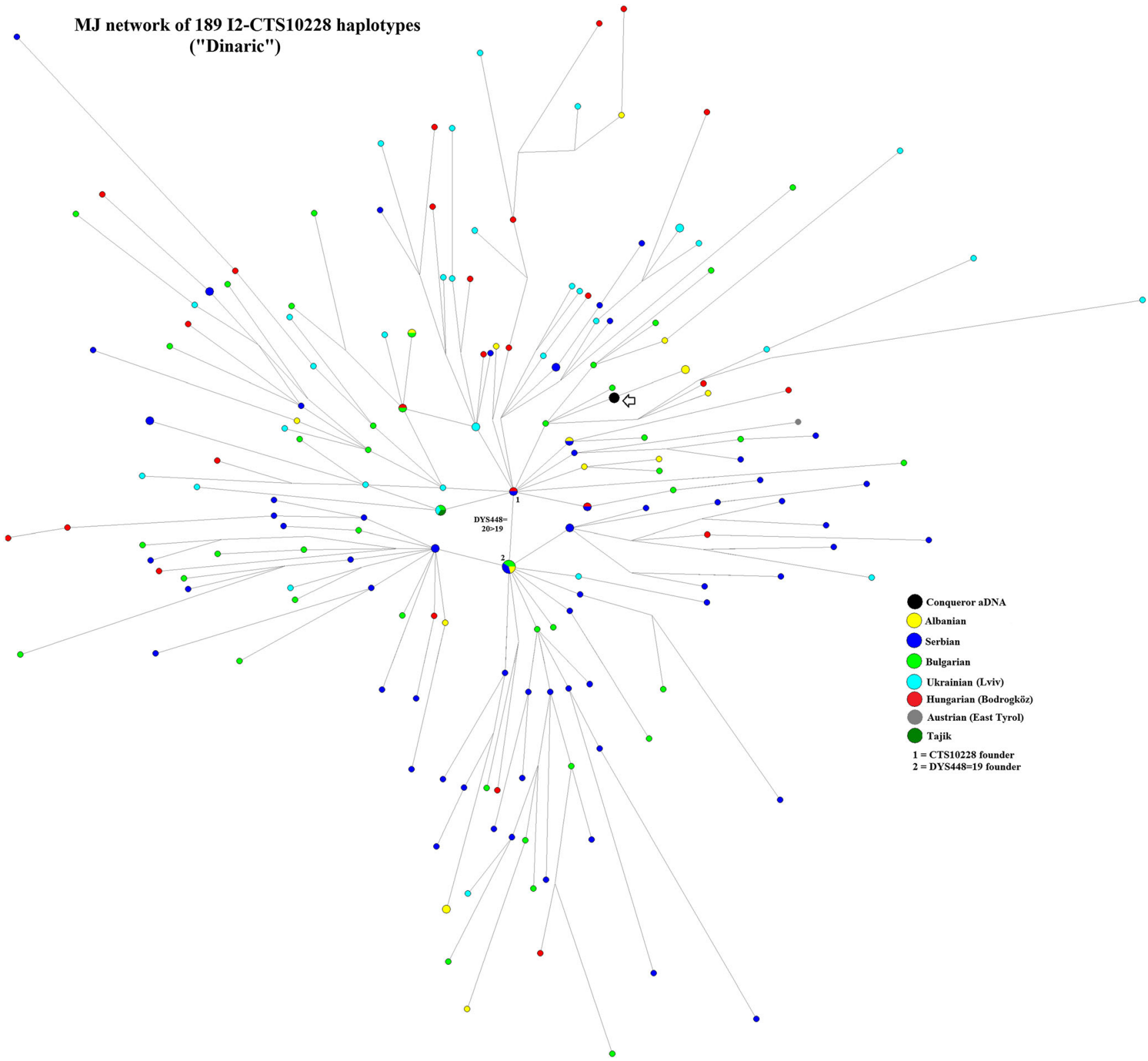

Fig. 7 The network of the I2a1-L621, CTS10228 haplogroup. The haplotype of Karos samples is marked with an arrow. Source of haplotypes: Di Cristofaro et al. (2013); Karachanak et al. (2013);

are considered as proto-Indo-European of the early Bronze Age Pit Grave (Yamna) culture (Allentoft et al. 2015).

\section{Rétközberencs-Paromdomb, graves 1 (RP/1) and 2 (RP/2): G2a2-U1, L1266}

The genetic markers of the two male individuals from Rétközberencs-Paromdomb graves 1 and 2 are identical, thus, they might be close relatives. The samples' haplotype may belong either to the G2a2-L1259 group U1(xL13) that had spread with the early agriculturers or to the L1266 subgroup (see Fig. 9), which, according to Rootsi et al. (2012), gave rise
Mielnik-Sikorska et al. (2013); Mirabal et al. (2010); Niederstätter et al. (2012); Pamjav et al. (2017); and Sarno et al. (2016)

to the patrilineal branch of the Northwestern Caucasian peoples (Abkhazians, Abazins, Adyghes/Circassians, and Kabardians). This group also admixed significantly to the gene pool of Northern Caucasian Turkic-speaking peoples (Karachays, Balkars, Kumyks, and Nogais).

Karos-Eperjesszög l, grave 3 (KEI/3) and Rakamaz-Túróczi part, grave 7 (RT/7): G2a1-P18, L293

These two skeletal remains yielded results on comparatively few loci, thus, a network for them could not be created. Based on the existing STR analyses, they most likely belong to the 


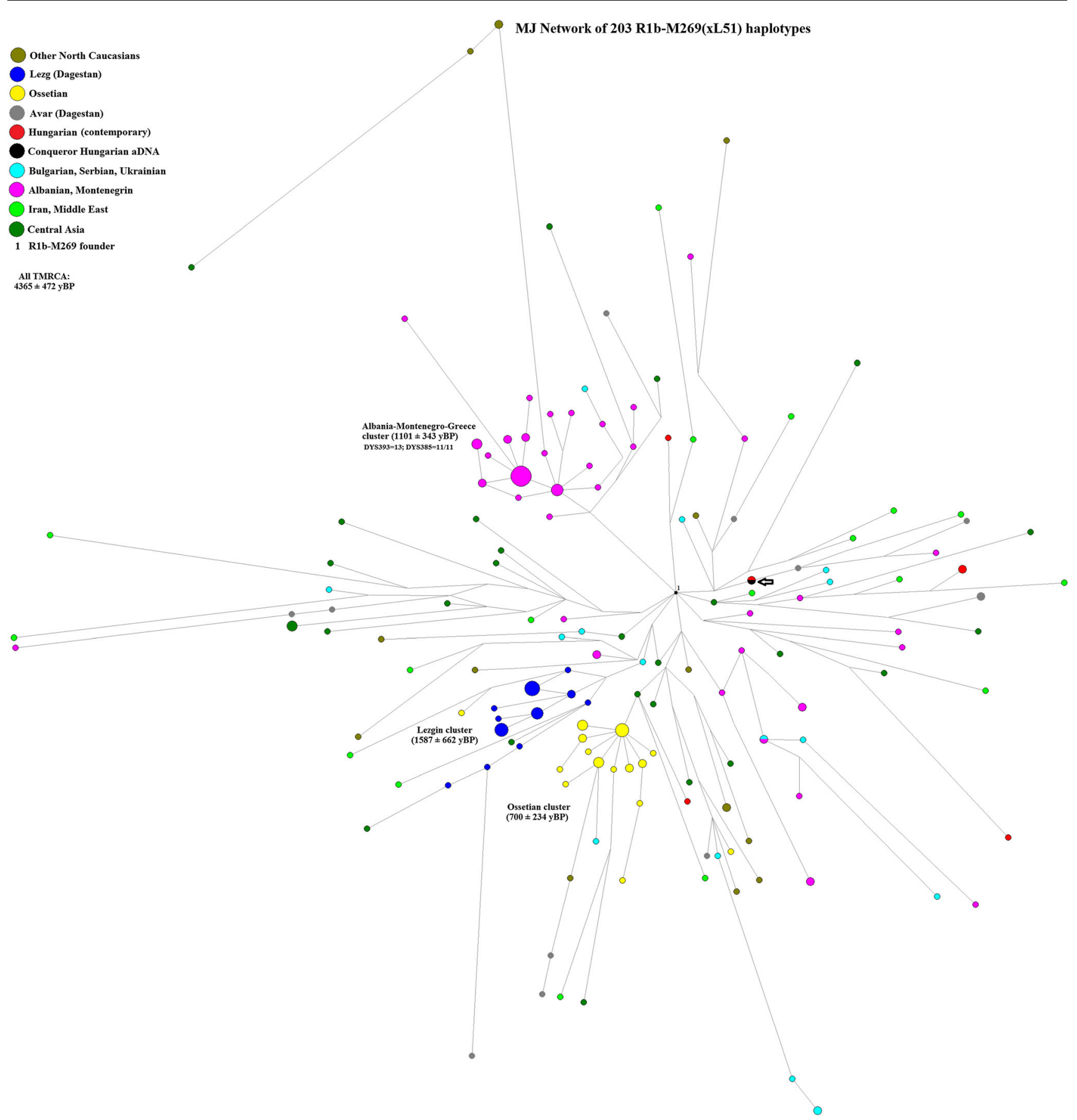

Fig. 8 The network of the R1b-M269 haplogroup. We placed the haplotype among Myres et al.'s (2011) L23(xM412) samples ( $n=203$ individuals). The sample from the Tiszaeszlár cemetery is a full genetic match with a modern Hungarian sample from Bodrogköz (Pamjav et al. 2017) on the 17 markers used in the network (marked with arrow). There is a $1-$ 1 mutation step deviation on 2 frequently mutating markers (DYS570 and DYS576) that are not in the network, which is in accord with the

G2a1-L293 subgroup, which is characteristic of the Northern Caucasian, Iranian-speaking Ossetians. Ten markers from the Rakamaz skeletal remains were examined and yielded 7 matches among the ethnicities from Balanovsky et al.'s (2011) study: 1 Ossetian P18 sample (2 genetic steps away), observation that the male from Bodrogköz is a direct descendant of either the research individual or the research individual's close genetic relative. The two samples are 1 genetic step away on 17 loci from a Northeast Caucasian (from Dagestan) Avar sample; this haplogroup may have entered the Hungarian Conqueror genome in the foreground of the Caucasus

4 Ossetians, 1 Dagestanian Avar, and 1 Abkhazian P18 sample (3 genetic steps away).

Only seven markers from the Karos skeletal remains could be compared with Balanovsky et al.'s (2011) study, of which the Karos grave 3 sample is a full genetic match with 1 


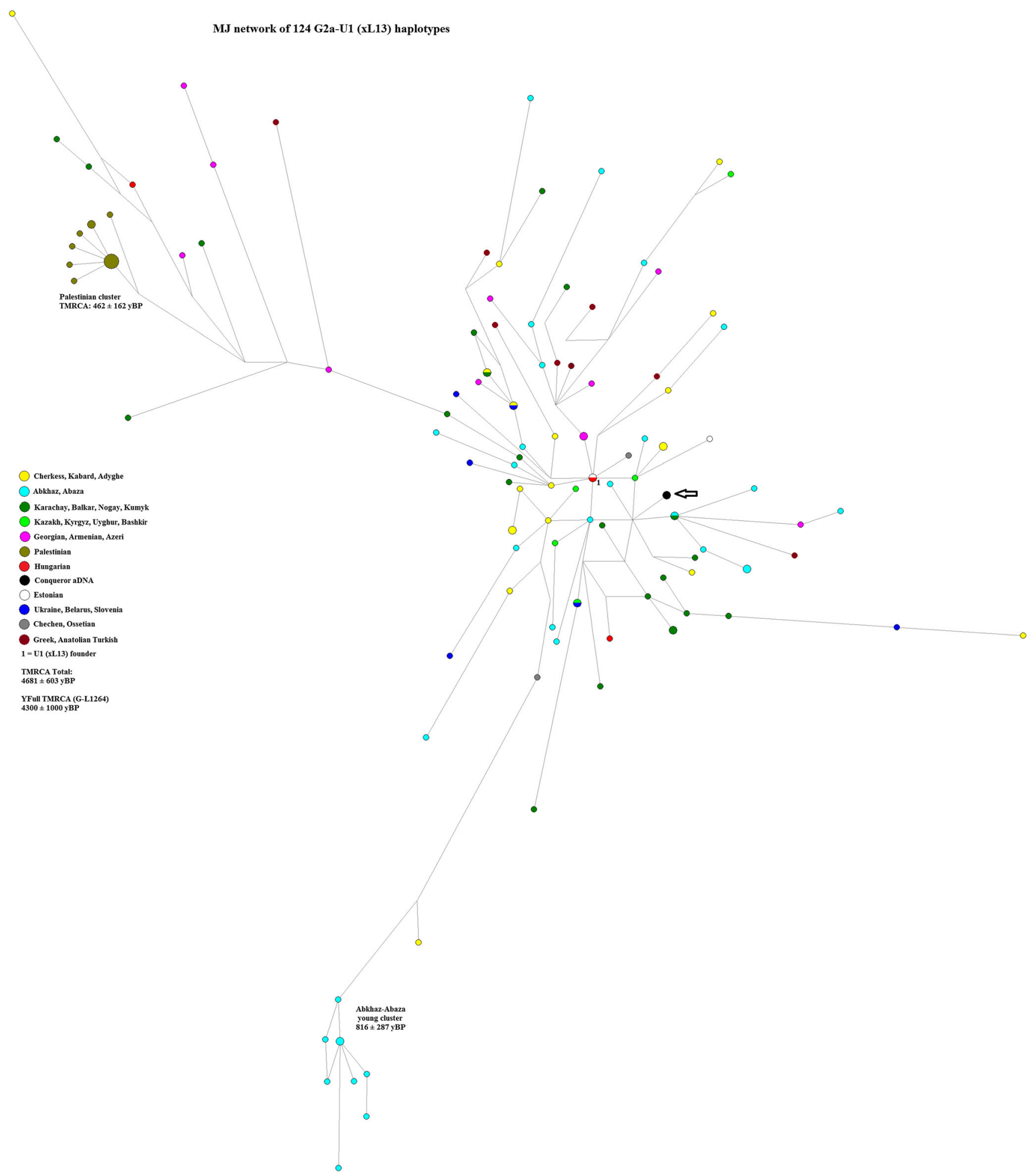

Fig. 9 Network of the G2a2-U1 haplogroup. There are no complete matches in the networks of either the YHRD database (https://yhrd.org/) or Rootsi et al.'s (2012) STR database ( $n=124$ individuals) for the analyzed Hungarian Conqueror samples (marked with an arrow). The closest match is 2 genetic steps away. This puts the common ancestor of the Hungarian Conqueror and the 2 Abkhazian, 1 Abazin, 1 Karachay, and 1 West Chinese Uyghur samples in the early Khazar period. Interestingly, despite the Caucasian nature of the group, the founder haplotype matches only with a modern Hungarian and an Estonian sample (https://www. familytreedna.com/public/G-L293/default.aspx?section=yresults), from which the Hungarian Conqueror samples are found 3 mutation steps away. The group could have been incorporated into the Hungarian Conquerors' gene pool in the foreground of the Caucasus 
Ossetian, 1 Abkhazian, and 1 Circassian. A further 9 Ossetians, 5 Chechens, 3 Circassians, and 2 Abkhazians are 1 genetic step away. However, due to the low number of comparable markers, these matches do not necessarily suggest a close genetic relationship. None of the G2a1-L293 samples has a known modern Hungarian descendant, nor can they be relatives due to the multiple genetic differences.

\section{Genetic distance calculations}

In our analysis of the Hungarian Conquerors' ancestry, $F_{\mathrm{ST}}$ (fixation index) genetic distances and $p$ values were calculated between Y-chromosomal packages of 73 ethnic groups, including modern Hungarian populations and Hungarian Conqueror samples. The modern Hungarian population is represented by the Bodrogköz (HUB) (Pamjav et al. 2017), Csángó (CNG) (Fehér et al. 2015), and Sekler/Székely (SE2) (Csányi et al. 2008) ethnic groups. In the comparative study, the populations were characterized by the frequencies of haplogroups (see Online Resource 5; ESM_5).

The Hungarian Conquerors (HUC) are represented by 16 independent paternal lineages. As shown in the medianjoining network analyses, the Hungarian Conquerors are particularly heterogeneous and their Y chromosomes originate from several different places, rather than from a single region, so we have separated the HUC samples into two, more homogeneous subgroups: the Northern Pontic (HUP) and the UralAltaic (HUA).

2555 out of a total $2628 F_{\mathrm{ST}}$ genetic distance calculations had statistically significant values $(p<0.05)$, while 73 comparisons had a $p$ value above the threshold (see Online Resource 6; ESM_6). The high $p$ values may be explained by nearby populations having such low $F_{\mathrm{ST}}$ genetic distances so as to be insignificant (e.g., SKW-POL $F_{\mathrm{ST}}=$ $0.00479 ; p=0.18919$ ), or one of the compared populations' sample sizes being too small (e.g., HUP-ARM $F_{\mathrm{ST}}=0.07899$; $p=0.10811)$. The highest $p$ values are explained by a combination of the aforementioned reasons (e.g., HUA-UDM $F_{\mathrm{ST}}=$ $0.01763 ; p=0.24324)$. Some of the $F_{\mathrm{ST}}$ values are negative, which suggests that the interpopulational genetic distances are smaller than the intrapopulational genetic distances.

15-15 comparisons were insignificant between the modern populations and the two Hungarian Conqueror groups (HUP and HUA). There is no overlap between the HUP and HUA related populations, all 30 are unique (see online Resource 6; ESM_6 and Fig. 10).

The $F_{\text {ST }}$ values between the Ural-Altaic subgroup (HUA) and Karelians (KRL), Estonians (EST), Saami (LAP), Eastern Finns (FIE), Northern Russians (RUN), Lithuanians (LIT), Latvians (LAT), Besermyan (BES), Udmurts (UDM), KomiZyrians (KOM), Mari (MRI), Chuvash (CHU), Tatars (TAT), Khanty (KHA), and the Buryats (BRY) are not statistically significant.
The $F_{\mathrm{ST}}$ values between the Pontic Hungarian Conqueror subgroup (HUP) and the Cherkess/Circassians (CHR), Kabards (KAB), Adyghe/Circassians (ADG), Balkars (BLK), Abkhazians (ABH), Ossetians (OSE), Karachays (KAR), Kuban Nogais (NKU), Kumyks (KUM), Georgians (GEO), Armenians (ARM), Sardinians (SRD), MiddleNeolithic Europeans (MDN), Neolithic Hungarians (NEH), and the Neolithic German and Spanish (NGS) samples are not statistically distinguishable.

Genetic distances are depicted on an NMDS plot (Fig. 10). HUA and HUP groups are separately placed with distinct neighboring populations.

The Ural-Altaic (HUA) subgroup fits within the FinnoUgric-speaking peoples (Estonians, Karelians, Eastern Finns, Saami, Besermyan, Komi, Udmurts, Khanty, and Mansi) and is close to their neighbors, the Tatars, Chuvash, Buryats, Latvians, Northern Russians, and the Lithuanians.

The Northern Pontic (HUP) samples fall far away from the other Hungarian Conqueror subgroup samples and also appear in other ethnic settings. Their closest ethnic groups are predominantly Caucasian (Kabardins, Adyghe/Circassians, Balkars, Cherkess/Circassians, Abkhazians, Georgians, Karachays, Kumyks, and Kuban Nogais). Based on the high frequency of $\mathrm{Hg} \mathrm{G}$, the Hungarian, the Middle-Neolithic European, the Neolithic German and Spanish, the Maltese, and the Sardinian groups are also close to each other.

\section{Discussion}

Several studies on the genetic origins of Hungarians have been published within the last decade, but the number of unanswered questions remained high. Furthermore, past studies on skeletons from the Hungarian Conquest Period focused on the maternal lineage, whereas familial ties are patrilineal among peoples of the Eurasian steppes, as well as among the ancient Hungarians. This is why we focused on Ychromosomal analyses to determine the genetic makeup of the people who arrived in the Carpathian Basin with the Hungarian tribes at the end of the ninth century CE.

\section{The ancient homeland}

Our analyses show that the paternal lineages of the Hungarian Conquerors are probably originated from three different larger regions far away from each other (see Fig. 11).

\section{Altai-Lake Baikal-Tian Shan: "Altaic component"}

Five samples originate from this area, which is the farthest away from Hungary. The individual from Karos II grave 60 (C2-M86 haplogroup) is from the Turkic-speaking regions of Kazakhstan and the Altai Mountains. The individuals from Tuzsér grave 6 


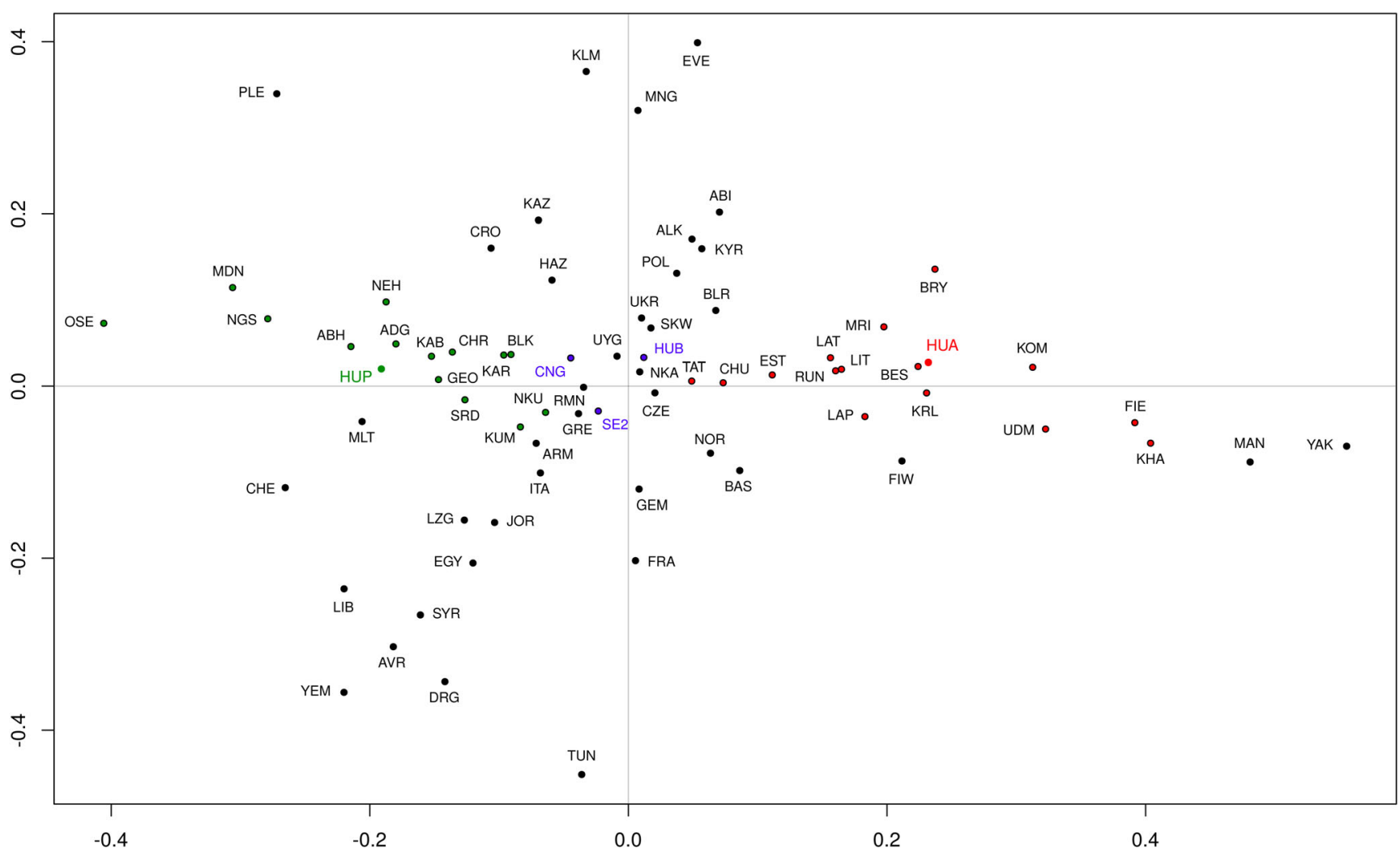

Fig. 10 A two-dimensional NMDS plot depicting the $\mathrm{F}_{\mathrm{ST}}$ data based on haplogroup frequency. The samples whose $\mathrm{F}_{\mathrm{ST}}$ genetic distances are statistically insignificant to the Ural-Altaic (HUA) and the Northern Pontic (HUP) subgroups are marked by the red and green points, respectively.

and Örménykút 52/50 (both N3a2-M2118) are from the region around Lake Baikal/Southern Siberia, where the Turkicspeaking Yakut also originate, whereas the individuals from Karos II grave 61 and Nagykörös grave 2 (both R1a-Z93) are from South-Central Asia, near Turkic- and Iranian-speaking peoples. Although one of the R1a-Z93 samples is only a single step away (on 16 loci) from a Khazar sample in the medianjoining network, the distribution of the Z93 branch (Rozhanskii and Klyosov 2012) and the nearby Kyrgyz hits point towards Central Asian ancestry. It is also possible that a Khazar descent joined the ancient Hungarian tribes in Khazaria.

Olasz et al. (2018) studied the genetic origins (17-loci haplotype) of King Béla III of the Árpád dynasty and found that the paternal lineage of the Hungarian royal dynasty also belonged to Hg R1a. The authors did not conduct SNP testing; however, based on the haplotype data, the sample would likely belong to the Z93 branch. SNP testing should be done to verify our hypothesis.

These five samples are still not enough to draw any farreaching conclusions, but they do allow us to determine that this group of Hungarian Conquerors was likely represented by two or three tribes, which migrated separately west across Eurasia.

According to Fettich (1935), the metalworks of the Hungarian Conquest period (and of the Avar period) were
The modern Hungarian population representing ethnic groups (Bodrogköz (HUB), Csángó (CNG), and Sekler/Székely (SE2)) are marked by blue

formed in the Minusinsk Depression in Southern Siberia. He believed that parallels of artifacts from the Hungarian Conquest period were found to the east and west of the Yenisei River, partly on the Abakan steppes, as well as in the areas surrounding Lake Baikal and the Altai Mountains, with the greatest amount in the Minusinsk Depression. His work remained almost completely without echo in the area of archaeology and history, which almost exclusively refers to the concept of the Uralian homeland.

However, half a century later, anthropological studies also confirmed the importance of this geographical region in Hungarian prehistory. Tóth (1981) and Éry (1983) were the first in anthropology to recognize that some of the conquering Hungarians were of Asian origin.

Anthropological studies based on craniometric comparisons of Hungarian Conquest period samples suggest that possible homeland of one part of the ancient Hungarian tribes, in addition to the abovementioned geographical regions, fall within South-Central Asia: Isfana, Fergana Valley, and the region of the Tian Shan (Fóthi 2014).

Recent results in the field of archaeogenetics highlight the same regions as an important source of Hungarian ethnogenesis (Neparáczki et al. 2018, 2019). According to the median-joining network analysis of our study, one of the 


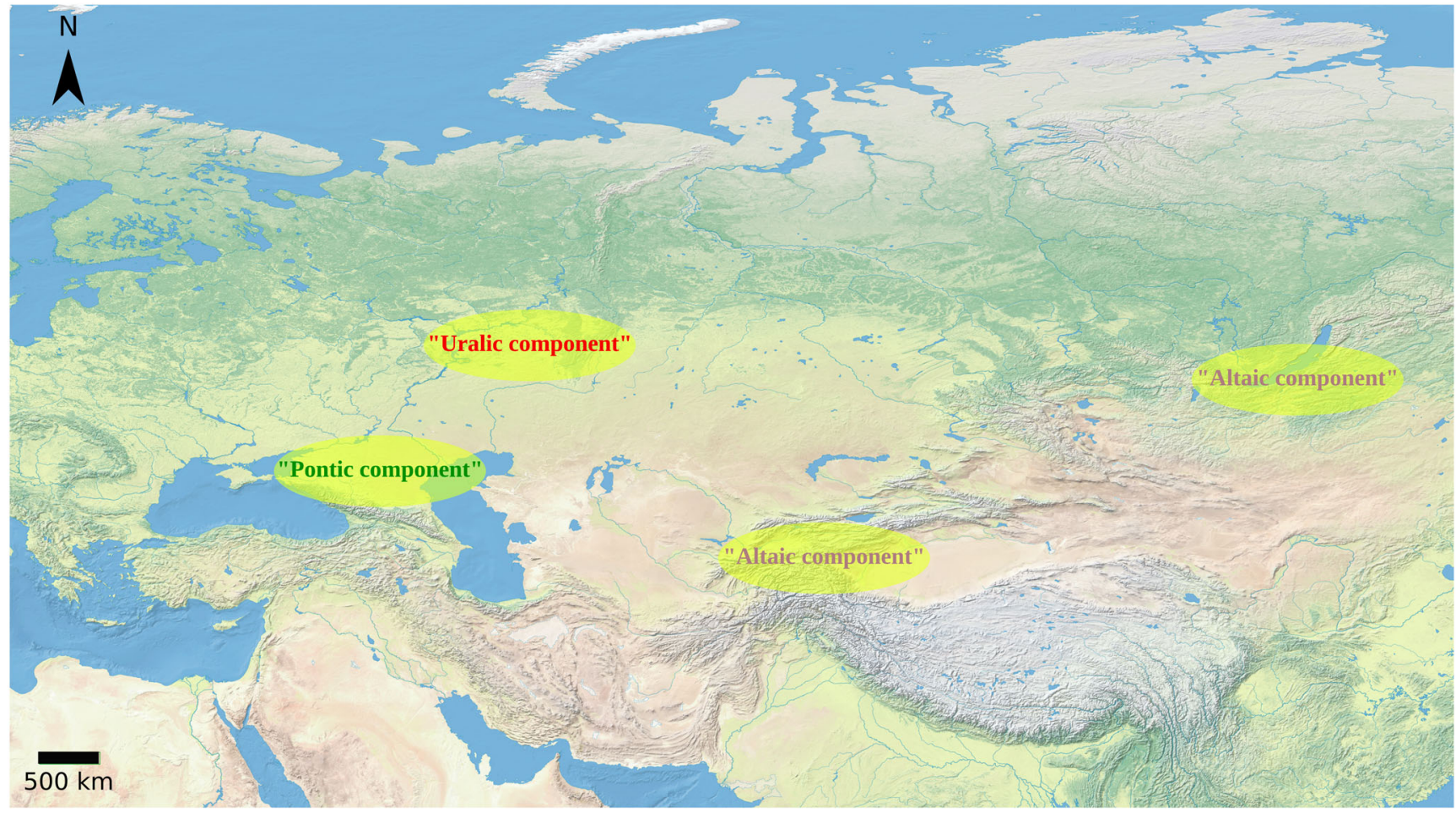

Fig. 11 The approximate geographic origins of the three genetic sources of the ancient Hungarian paternal lineages based on DNA genotyping of 19 Hungarian Conquerors

R1a-Z93 samples (Karos II grave 61) is from South-Central Asia (Tajik and Kyrgyz regions), and R1a-Z93 also dominates the paternal lineage of the Pashtuns living in the surrounding area (Underhill et al. 2015).

The anthropological and subsequent genetic results will hopefully inspire further archaeogenetic research, beyond archaeology, history, and linguistics, to reveal the details of this still barely known area of Hungarian prehistory.

The results of our genetic study are in agreement with the anthropological results outlined above. Both the calculated STR-based age of the N3a2 subgroup (1970-2070 \pm 690 years; i.e., the period of the Asian Huns) and the geographic location of the homologous cases suggest that these samples may have belonged to the Hun/Turkish line of the Hungarian Conquerors. The two N3a2 and C2-M68 Hungarian Conqueror warriors may have originated from the area between Lake Baikal and the Altai Mountains, while the R1a-Z93 warriors may have been from the Tian Shan in South-Central Asia.

The widespread area from the Altai Mountains to the Tian Shan reaches the edge of the Asiatic Hunnic/Xiongnu territory. Several skeletal remains of Asiatic Huns/Xiongnu have been discovered, such as from the Egyin Gol cemetery with haplogroups Q-M242, N1c, (N3a in modern terminology), and C3-M130 (Keyser-Tracqui et al. 2003; Kang et al. 2013) and the Duurlig Nars site with haplogroups: C3-M130 and R1a1 (Kim et al. 2010) in Northern Mongolia. To the southern part of the Asiatic Huns' territory (China), only males with Q haplogroups were found in the Xiongnu cemeteries. In Xinjiang (Barköl Kazakh Autonomous County), the 13 examined ancient individuals belonged to haplogroup Q (Q-M346, Q*, Q1a, and Q1b) (Kang et al. 2013), and in Pengyang, each of the 4 examined skeletons also belonged to haplogroup Q (Zhao et al. 2010). We found 2 haplogroups among the Hungarian Conqueror skeletal remains, which are present in Southern Siberian and Central Asian samples of the Xiongnu period (R1a and N3a2), but there were no Q haplogroup individuals in the research sample.

Damgaard et al. (2018) describe a Y-DNA and autosomal genetic shift in the Baikal region between the Baikal Early Neolithic (Y-Hg N and a mix of Ancient North Eurasian and Ancient East Asian autosomal components) and the Baikal Late Neolithic/Early Bronze Age (arrival of Y-Hg Q and additional Ancient East Asian components). This supports the assumption that proto-Uralic populations migrated to the West and were replaced by possible proto-Altaic populations during the 1500-year period that separates the Baikal Neolithic from the Early Bronze Age which would imply that later Xiongnu/ Huns spoke a Turkic language through autosomal aDNA analysis.

\section{Volga-Kama-Ural Mountains: “Uralic component"}

In the case of five Hungarian Conqueror samples (Karos II graves 14 and 29, Bodrogszerdahely grave 3, Nagykörü grave 6 , and Tiszakécske grave 1), the analysis yielded genetic hits 
partly from Siberia (Mansi and Khanty peoples) and partly from the area between the Volga-Kama Rivers and the Ural Mountains.

All five samples belong to the N3a4-Z1936 subgroup, from which the Balto-Finnic branch (N3a4-B535/Z1934Z1925) split 4900 years ago, which is roughly in line with the time of the disunion of Finnic and Ugric languages estimated by linguistics (around $4000 \mathrm{yBP}$ with dialects starting to diverge earlier; Hajdú and Domokos 1980). The N3a4-Z1936 subgroup branched out even further following the separation from the Finnic side: the modern representatives of the branch not carrying Z1934 and L1034 are known from Tatarstan and Hungary, and it has been found among the skeletal remains of Karos II graves 14 and 29, and Bodrogszerdahely grave 3 as well. The B539/Y13850 branch is found among the Volga Tatars in present-day Tatarstan, and we also found it in the genome of a modern Hungarian from Bodrogköz and in a Hungarian Conqueror warrior from Nagykörü grave 6. However, as we could not test each sample for Y13850, more Hungarian Conquerors may bear it as well. Based on the results of Post et al. 2019, most B539(xB540) samples should belong to the B545 clade ("brother" of B540). The L1034/ B540 branch is found in modern Bashkortostan, Tatarstan, the Ob-Ugric peoples of Siberia, Székelys, Hungarians living in Hungary, and also in the Hungarian Conqueror from Tiszakécske grave 1.

The genetic results support this group's Ugric linguistic classification; there were matches with modern peoples living in Bashkortostan and Tatarstan (Magna Hungaria), as well as with Hungarians' closest linguistic relatives, the Mansi and the Khanty in Siberia.

\section{Northern Pontus: "Pontic component"}

Based on genetic results, a heterogeneous group from the Northern Caucasus (northeastern shore of the Black Sea and the lower Don), in so-called Levedia, joined two other groups (Altaic and Uralic components) originating from east. Nine Hungarian Conqueror samples show four haplogroups characteristic of the Northern Pontic/Ciscaucasian region (G2a, I2a, J1, and R1b).

Among the samples belonging to the G2a haplogroup, two closely related individuals from Rétközberencs match completely. They belong to the G2a2-U1, L1266 subgroups, which share the paternal lineages of the peoples of the Northwestern Caucasus, such as the Abkahzians, Abazins, Adyghe (Circassians), Circassians, and Kabardians. Although the other two analyzed Hungarian Conqueror males (from Karos I grave 3 and Rakamaz grave 7) were not related, they both belonged to the G2a1-L293 subgroup, which is characteristic of the Ossetians from the Northern Caucasus. The Caucasian origins of both G2a subgroups is certain; however, this region was the most affected by migration during the time of the Khazar polity. In this period, a native Caucasian group might join the Hungarian Conquerors. Research about the Kabar tribe that left the Khazars and accompanied the ancient Hungarians would likely begin with this Caucasian group.

Three I2a males were present in the sample, with haplotypes I2a1-L621, CTS10228. The males from Karos II grave 52 and Karos III grave 11 were buried with artifacts suggesting they were leaders among the Hungarian Conquerors (Révész 1996).

The SNP-based age of the Eastern European CTS10228 branch is $2200 \pm 300$ years old. The carriers of the most ancient subgroup live in Southeast Poland, and it is likely that the rapid demographic expansion which brought the marker to other regions in Europe began there. The largest demographic explosion occurred in the Balkans, where the subgroup is dominant in $50.5 \%$ of Croatians, $30.1 \%$ of Serbs, $31.4 \%$ of Montenegrins, and in about $20 \%$ of Albanians and Greeks. As a result, this subgroup is often called Dinaric. It is interesting that while it is dominant among modern Balkan peoples, this subgroup has not been present yet during the Roman period, as it is almost absent in Italy as well (see Online Resource 5; ESM_5).

The Hungarian Conqueror tribe whose leaders were buried at Karos may be connected to an early wave of this dynamic population expansion. Their genetic haplogroup, I2aCTS10228, is widespread among Slavs, but it is only present in $7 \%$ of Caucasian peoples, namely among the Karachay.

Although we were unable to analyze the Karos remains any deeper, we did test the closest modern Hungarian Kunszentmárton samples for further mutations. It belonged to the A815 subgroup, which is also present in the Northern Caucasian Karachays, and possibly due to historical Hungarian impact, in the Moravians in the Czech Republic, the Slovaks, and the Ukrainians.

As such, it appears that the I2a-CTS10228 haplogroup in the paternal lineage of the Karos leaders arises from a specific branch in the Northern Caucasus dating to about 400-500 CE. Its modern descendents live among the Karachay, Hungarians, and various other surrounding nationalities.

\section{Comparison of paternal and maternal lineages}

The maternal lineages were simultaneously analyzed by another team (Neparáczki et al. 2018). Despite the large difference in the number of examined cases (19 paternal versus 102 maternal lineages), there was some overlap between the cases of the two analyses. Out of the 19 paternal samples, only 8 samples were included in the mtDNA analysis $(8 / 19,42.1 \%$ versus $8 / 102,7.8 \%$ ); nevertheless, the results show agreement. The maternal lineages originate from approximately the same three areas as the paternal lineages: Central-Inner Asia, Middle-Volga Region and the Pontic-Caspian steppe. 
Several female samples were also included in the mtDNA analysis; thus, based on these two analyses, it can be assumed that along with man, a significant number of women arrived in the Carpathian Basin as well.

It should be noted that, while the genetic analogues of the paternal lineages originate from three well-defined areas, the genetic analogues of the maternal lineages are more diverse and come from a much larger area. The homeland of the three components of the Hungarian tribes is more clearly defined from the paternal than the maternal lineages, which supports the initial hypothesis that the patrilocal exogamy of nomadic peoples makes paternal lineages more suitable to genetic origins research. Testing autosomal aDNA components in the future would be useful to see the whole picture of genetic heritage for the Hungarian Conquerors.

It is also likely that migration to the Carpathian Basin from even the farthest areas did not take hundreds of years, contrary to the long-held opinion in the Hungarian scientific world.

\section{Question of linguistic relationships}

The most controversial topic in the research of ancient Hungarian history is the language of the Hungarian Conqueror tribes. In addition to the Uralic (Finno-Ugric) language theory, there exist others that we do not cover in our study, but the results of our genetic analyses may shed light on linguistic relations. The $\mathrm{N}$ haplogroup is dominant in every branch of the Uralic language family (Zerjal et al. 1997), except in the Hungarians (Semino et al. 2000; Csányi et al. 2008; Pamjav et al. 2017). The first genetic research on Hungarian Conquest period remains (Csányi et al. 2008) showed that two out of four classic Hungarian Conqueror samples belonged to the N-Tat haplogroup. Our present study suggests that the Y chromosomes that are very characteristic to the most of the Uralic-speaking populations - except modern Hungarianswere frequent among the Hungarian Conquerors who might have been the ones who brought the Uralic language to the Carpathian Basin, where it is spoken also today.

Our analyses allowed us to examine the N-Tat samples in greater genetic detail. For example, five samples had the genetic characteristics of the Ugric N3a4 branch and geographically localized to the Ural Mountains, while two samples belonged to the $\mathrm{N} 3 \mathrm{a} 2$ branch, which diverged from the Ugrics' ancestors 6800 years ago (Ilumäe et al. 2016), and is now found among the Turkic-speaking peoples, in the area surrounding Lake Baikal, especially among the Yakuts, who originated from there (Crubézy et al. 2010; Ilumäe et al. 2016). Byzantine sources (Pauler and Szilágyi 1990) mention the bilingualism in the Hungarian tribes (then called Turks). Our current results do not yet allow us to take a stand on this issue, but they inspire us to continue our research in this direction in the future.

\section{Conclusion}

Based on the 19 Hungarian Conqueror elite warriors we examined, the paternal lineage of the Hungarian Conquerors is genetically quite heterogeneous. Of the three components, one was from present-day Bashkortostan in the Ural Mountains, while a second came from Inner Asia, most likely surviving elements from the Xiongnu Empire. These groups may have been joined by a third one in the Caucasus that was composed of several different ancestries, such as Northern Caucasian Turk, Alan, and Eastern European (perhaps early Slavs).

The existence of the three relevant components is not affected by the relatively small sample size, but if more samples could be included in future analyses, then new elements and changes in the ratios would be likely to arise.

Despite these new results, there still remain several questions concerning the demography of the Hungarian Conquerors that may be solved with autosomal, mtDNA, and Y-chromosomal studies on larger sample sets (both commoner and elite graves) from the Hungarian Conquest period, in conjunction with genetic analyses on skeletal remains from before and after the Hungarian Conquest period.

Acknowledgments We are grateful to Prof. Miklós Maróth for his support, to Éva Mayer for her administrative work, to Eszter Dudás and Dr. Zoltán Szabolcsi for sample collection, and to Dr. Horolma Pamjav for her multifaceted and magnanimous help. We owe special thanks to Nicola Brackett for the grammatical revision of the article.

Funding Information Open access funding provided by Hungarian Natural History Museum (MTM). This research was supported by the Hungarian Funds No. GF/JSZF/814/9/2015 and No. ZH690024.

\section{Compliance with ethical standards}

Conflict of interest The authors declare that they have no conflict of interest.

Open Access This article is licensed under a Creative Commons Attribution 4.0 International License, which permits use, sharing, adaptation, distribution and reproduction in any medium or format, as long as you give appropriate credit to the original author(s) and the source, provide a link to the Creative Commons licence, and indicate if changes were made. The images or other third party material in this article are included in the article's Creative Commons licence, unless indicated otherwise in a credit line to the material. If material is not included in the article's Creative Commons licence and your intended use is not permitted by statutory regulation or exceeds the permitted use, you will need to obtain permission directly from the copyright holder. To view a copy of this licence, visit http://creativecommons.org/licenses/by/4.0/.

\section{References}

Allentoft ME, Sikora M, Sjögren K-G, Rasmussen S, Rasmussen M, Stenderup J, Damgaard PB, Schroeder H, Ahlström T, Vinner L, Malaspinas A-S, Margaryan A, Higham T, Chivall D, Lynnerup 
N, Harvig L, Baron J, Della CP, Dąbrowski P, Duffy PR, Ebel AV, Epimakhov A, Frei K, Furmanek M, Gralak T, Gromov A, Gronkiewicz S, Grupe G, Hajdu T, Jarysz R, Khartanovich V, Khokhlov A, Kiss V, Kolář J, Kriiska A, Lasak I, Longhi C, McGlynn G, Merkevicius A, Merkyte I, Metspalu M, Mkrtchyan R, Moiseyev V, Paja L, Pálfi G, Pokutta D, Pospieszny Ł, Price TD, Saag L, Sablin M, Shishlina N, Smrčka V, Soenov VI, Szeverényi V, Tóth G, Trifanova SV, Varul L, Vicze M, Yepiskoposyan L, Zhitenev V, Orlando L, Sicheritz-Pontén T, Brunak S, Nielsen R, Kristiansen K, Willerslev E (2015) Population genomics of Bronze Age Eurasia. Nature 522:167-172. https://doi.org/10.1038/ nature 14507

Balanovsky O, Dibirova K, Dybo A, Mudrak O, Frolova S, Pocheshkhova E, Haber M, Platt D, Schurr T, Haak W, Kuznetsova M, Radzhabov M, Balaganskaya O, Romanov A, Zakharova T, Soria Hernanz DF, Zalloua P, Koshel S, Ruhlen M, Renfrew C, Wells RS, Tyler-Smith C, Balanovska E, Genographic Consortium (2011) Parallel evolution of genes and languages in the Caucasus region. Mol Biol Evol 28:2905-2920. https://doi.org/10. 1093/molbev/msr126

Bálint C (2006) Az etnosz a korai középkorban (A kutatás lehetőségei és gátjai) [Ethnos in the Early Middle Ages (The possibilities and limits of research)]. Századok 140:277-347

Bandelt HJ, Forster P, Rohl A (1999) Median-joining networks for inferring intraspecific phylogenies. Mol Biol Evol 16:37-48. https://doi. org/10.1093/oxfordjournals.molbev.a026036

Bíró A, Fehér T, Bárány G, Pamjav H (2015) Testing Central and Inner Asian admixture among contemporary Hungarians. Forensic Sci Int Genet 15:121-126. https://doi.org/10.1016/j.fsigen.2014.11.007

Crubézy E, Amory S, Keyser C, Bouakaze C, Bodner M, Gibert M, Röck A, Parson W, Alexeev A, Ludes B (2010) Human evolution in Siberia: from frozen bodies to ancient DNA. BMC Evol Biol 10: 25. https://doi.org/10.1186/1471-2148-10-25

Csányi B, Bogácsi-Szabó E, Tömöry G, Czibula Á, Priskin K, Csõsz A, Mende B, Langó P, Csete K, Zsolnai A, Conant EK, Downes CS, Raskó I (2008) Y-chromosome analysis of ancient Hungarian and two modern Hungarian-speaking populations from the Carpathian Basin. Ann Hum Genet 72:519-534. https://doi.org/10.1111/j.14691809.2008.00440.x

Csősz A, Szécsényi-Nagy A, Csákyová V, Langó P, Bódis V, Köhler K, Tömöry G, Nagy M, Mende BG (2016) Maternal genetic ancestry and legacy of 10th century AD Hungarians. Sci Rep 6:33446. https://doi.org/10.1038/srep33446

Damgaard P d B, Marchi N, Rasmussen S, Peyrot M, Renaud G, Korneliussen T, Moreno-Mayar JV, Pedersen MW, Goldberg A, Usmanova E, Baimukhanov N, Loman V, Hedeager L, Pedersen AG, Nielsen K, Afanasiev G, Akmatov K, Aldashev A, Alpaslan A, Baimbetov G, Bazaliiskii VI, Beisenov A, Boldbaatar B, Boldgiv B, Dorzhu C, Ellingvag S, Erdenebaatar D, Dajani R, Dmitriev E, Evdokimov V, Frei KM, Gromov A, Goryachev A, Hakonarson H, Hegay T, Khachatryan Z, Khaskhanov R, Kitov E, Kolbina A, Kubatbek T, Kukushkin A, Kukushkin I, Lau N, Margaryan A, Merkyte I, Mertz IV, Mertz VK, Mijiddorj E, Moiyesev V, Mukhtarova G, Nurmukhanbetov B, Orozbekova Z, Panyushkina I, Pieta K, Smrčka V, Shevnina I, Logvin A, Sjögren K-G, Štolcová T, Taravella AM, Tashbaeva K, Tkachev A, Tulegenov T, Voyakin D, Yepiskoposyan L, Undrakhbold S, Varfolomeev V, Weber A, Wilson Sayres MA, Kradin N, Allentoft ME, Orlando L, Nielsen R, Sikora M, Heyer E, Kristiansen K, Willerslev E (2018) 137 ancient human genomes from across the Eurasian steppes. Nature 557: 369-374. https://doi.org/10.1038/s41586-018-0094-2

Di Cristofaro J, Pennarun E, Mazières S, Myres NM, Lin AA, Temori SA, Metspalu M, Metspalu E, Witzel M, King RJ, Underhill PA, Villems R, Chiaroni J (2013) Afghan Hindu Kush: where Eurasian subcontinent gene flows converge. PLoS One 8:e76748. https://doi. org/10.1371/journal.pone. 0076748
Duggan AT, Whitten M, Wiebe V, Crawford M, Butthof A, Spitsyn V, Makarov S, Novgorodov I, Osakovsky V, Pakendorf B (2013) Investigating the prehistory of Tungusic peoples of Siberia and the Amur-Ussuri region with complete mtDNA genome sequences and Y-chromosomal markers. PLoS One 8:e83570. https://doi.org/10. 1371/journal.pone.0083570

Éry K (1977) Embertani adatok a Felső-Tiszavidék X. századi népességéhez [Anthropological data for the 10th century CE populations of the Upper Tisza Region]. Anthrop Közl 21:15-30

Éry K (1983) Újabb összehasonlító statisztikai vizsgálatok a Kárpátmedence 6-12. századi népességének embertanához [further comparative statistical analyses on the 6th-12th centuries CE human populations of the Carpathian Basin]. Veszprém Megyei Múzeumok Közleményei 16:35-85

Excoffier L, Lischer HEL (2010) Arlequin suite ver 3.5: a new series of programs to perform population genetics analyses under Linux and Windows. Mol Ecol Resour 10:564-567. https://doi.org/10.1111/j. 1755-0998.2010.02847.x

Fehér T, Németh E, Vándor A, Kornienko IV, Csáji LK, Pamjav H (2015) Y-SNP L1034: limited genetic link between Mansi and Hungarianspeaking populations. Mol Gen Genomics 290:377-386. https://doi. org/10.1007/s00438-014-0925-2

Fettich N (1935) A honfoglaló magyarság fémművessége [Metalworks of the conquering Hungarians]. Arch Hung 21:1-303

Fóthi E (2014) A Kárpát-medence 6-11. századi történetének embertani vonatkozásai [Anthropological aspects of the history of the 6th-11th centuries CE Carpathian Basin]. In: Sudár B, Szentpéteri J, Petkes Z, Lezsák G, Zsidai Z (eds) Magyar őstörténet. Tudomány és hagyományőrzés [Ancient Hungarian History. Science and Tradition]. MTA Bölcsészettudományi Kutatóközpont, Budapest, pp 151-168

Goedbloed M, Vermeulen M, Fang RN, Lembring M, Wollstein A, Ballantyne K, Lao O, Brauer S, Krüger C, Roewer L, Lessig R, Ploski R, Dobosz T, Henke L, Henke J, Furtado MR, Kayser M (2009) Comprehensive mutation analysis of 17 Y-chromosomal short tandem repeat polymorphisms included in the AmpFISTR ${ }^{\circledR}$ Yfiler® PCR amplification kit. Int J Legal Med 123:471-482. https://doi.org/10.1007/s00414-009-0342-y

Guglielmino CR, De Silvestri A, Beres J (2000) Probable ancestors of Hungarian ethnic groups: an admixture analysis. Ann Hum Genet 64:145-159. https://doi.org/10.1017/S0003480000008010

Hajdú P, Domokos P (1980) Uráli nyelvrokonaink. [Our Uralian language relatives]. Tankönyvkiadó, Budapest

Hallast P, Batini C, Zadik D, Maisano Delser P, Wetton JH, Arroyo-Pardo E, Cavalleri GL, de Knijff P, Destro Bisol G, Dupuy BM, Eriksen HA, Jorde LB, King TE, Larmuseau MH, Lopez de Munain A, Lopez-Parra AM, Loutradis A, Milasin J, Novelletto A, Pamjav H, Sajantila A, Schempp W, Sears M, Tolun A, Tyler-Smith C, Van Geystelen A, Watkins S, Winney B, Jobling MA (2015) The Ychromosome tree bursts into leaf: 13,000 high-confidence SNPs covering the majority of known clades. Mol Biol Evol 32:661673. https://doi.org/10.1093/molbev/msu327

Ilumäe A-M, Reidla M, Chukhryaeva M, Järve M, Post H, Karmin M, Saag L, Agdzhoyan A, Kushniarevich A, Litvinov S, Ekomasova N, Tambets K, Metspalu E, Khusainova R, Yunusbayev B, Khusnutdinova EK, Osipova LP, Fedorova S, Utevska O, Koshel S, Balanovska E, Behar DM, Balanovsky O, Kivisild T, Underhill PA, Villems R, Rootsi S (2016) Human Y chromosome haplogroup $\mathrm{N}$ : a non-trivial time-resolved phylogeography that cuts across language families. Am J Hum Genet 99:163-173. https://doi.org/10. 1016/j.ajhg.2016.05.025

Kang L, Jin T, Wu F, Ao X, Wen S, Wang C, Huang Y, Li X, Li H (2013) $\mathrm{Y}$ chromosomes of ancient Hunnu people and its implication on the phylogeny of East Asian linguistic families. In: ASHG annual meeting. Boston, p 2041F 
Karachanak S, Grugni V, Fornarino S, Nesheva D, Al-Zahery N, Battaglia V, Carossa V, Yordanov Y, Torroni A, Galabov AS, Toncheva D, Semino O (2013) Y-chromosome diversity in modern Bulgarians: new clues about their ancestry. PLoS One 8:e56779. https://doi.org/10.1371/journal.pone.0056779

Keyser-Tracqui C, Crubézy E, Ludes B (2003) Nuclear and mitochondrial DNA analysis of a 2,000-year-old necropolis in the Egyin Gol Valley of Mongolia. Am J Hum Genet 73:247-260. https://doi.org/ $10.1086 / 377005$

Kim K, Brenner CH, Mair VH, Lee K-H, Kim J-H, Gelegdorj E, Batbold N, Song Y-C, Yun H-W, Chang E-J, Lkhagvasuren G, Bazarragchaa M, Park A-J, Lim I, Hong Y-P, Kim W, Chung S-I, Kim D-J, Chung Y-H, Kim S-S, Lee W-B, Kim K-Y (2010) A western Eurasian male is found in 2000-year-old elite Xiongnu cemetery in Northeast Mongolia. Am J Phys Anthropol 142:429-440. https://doi.org/10. 1002/ajpa.21242

Klyosov AA, Faleeva T (2017) Excavated DNA from two Khazar burials. Adv Anthropol 07:17-21. https://doi.org/10.4236/aa.2017.71002

Kustár Á (1996) A karos-eperjesszögi I-II-III. honfoglalás kori temetök embertani vizsgálata [Anthropological examination of the Hungarian Conqueror cemeteries of Karos-Eperjesszög]. In: Révész L A karosi honfoglalás kori temetők [The Hungarian Conqueror cemeteries of Karos-Eperjesszög], Miskolc, pp 395-456

Lahermo P, Laitinen V, Sistonen P, Béres J, Karcagi V, Savontaus M-L (2004) MtDNA polymorphism in the Hungarians: comparison to three other Finno-Ugric-speaking populations. Hereditas 132:3542. https://doi.org/10.1111/j.1601-5223.2000.00035.x

Lipták P (1952) New Hungarian skeletal remains of the 10th century from the Danube-Tisza plain. Annls hist-nat Mus natn hung 3:277-287

Lipták P (1957) Awaren und Magyaren in Donau-Theiss Zwischenstromgebeit (Zur Anthropologie der VII.-XIII. Jahrunderts). Acta Arch VIII:199-268

Lipták P (1983) Avars and ancient Hungarians. Akadémia Kiadó, Budapest

Madaras L (2014) Nagykörü. In: Sudár B, Petkes ZS (eds) A honfoglalók viselete [Apparel of the Hungarian Conquerors]. MTA BTK Magyar Östörténeti Témacsoport - Helikon, Budapest, (Magyar Östörténet I.), pp 75-81

Malán M (1956) L'Anthropologie du cimetiere de Bogrogszerdahely (Xe siecle). Crania Hung I:61-74

Malyarchuk B, Derenko M, Denisova G, Khoyt S, Woźniak M, Grzybowski T, Zakharov I (2013) Y-chromosome diversity in the Kalmyks at the ethnical and tribal levels. J Hum Genet 58:804-881. https://doi.org/10.1038/jhg.2013.108

Mendisco F, Keyser C, Hollard C, Seldes V, Nielsen AE, Crubézy E, Ludes B (2011) Application of the iPLEXTM gold SNP genotyping method for the analysis of Amerindian ancient DNA samples: benefits for ancient population studies. Electrophoresis 32:386-393. https://doi.org/10.1002/elps.201000483

Mielnik-Sikorska M, Daca P, Woźniak M, Malyarchuk BA, Bednarek J, Dobosz T, Grzybowski T (2013) Genetic data from Y chromosome STR and SNP loci in Ukrainian population. Forensic Sci Int Genet 7:200-203. https://doi.org/10.1016/j.fsigen.2012.05.007

Mirabal S, Varljen T, Gayden T, Regueiro M, Vujovic S, Popovic D, Djuric M, Stojkovic O, Herrera RJ (2010) Human Y-chromosome short tandem repeats: a tale of acculturation and migrations as mechanisms for the diffusion of agriculture in the Balkan Peninsula. Am J Phys Anthropol 142:380-390. https://doi.org/10.1002/ajpa.21235

Myres NM, Rootsi S, Lin AA, Järve M, King RJ, Kutuev I, Cabrera VM, Khusnutdinova EK, Pshenichnov A, Yunusbayev B, Balanovsky O, Balanovska E, Rudan P, Baldovic M, Herrera RJ, Chiaroni J, Di Cristofaro J, Villems R, Kivisild T, Underhill PA (2011) A major Y-chromosome haplogroup R1b Holocene era founder effect in central and Western Europe. Eur J Hum Genet 19:95-101. https://doi. org/10.1038/ejhg.2010.146
Neparáczki E, Juhász Z, Pamjav H, Fehér T, Csányi B, Zink A, Maixner F, Pálfi G, Molnár E, Pap I, Kustár Á, Révész L, Raskó I, Török T (2017) Genetic structure of the early Hungarian conquerors inferred from mtDNA haplotypes and Y-chromosome haplogroups in a small cemetery. Mol Gen Genomics 292:201-214. https://doi.org/10. 1007/s00438-016-1267-z

Neparáczki E, Maróti Z, Kalmár T, Kocsy K, Maár K, Bihari P, Nagy I, Fóthi E, Pap I, Kustár Á, Pálfi G, Raskó I, Zink A, Török T (2018) Correction: Mitogenomic data indicate admixture components of Central-Inner Asian and Srubnaya origin in the conquering Hungarians. PLoS One 13:e0208295. https://doi.org/10.1371/ journal.pone.0208295

Neparáczki E, Maróti Z, Kalmár T, Maár K, Nagy I, Latinovics D, Kustár Á, Pálfi G, Molnár E, Marcsik A, Balogh C, Lőrinczy G, Gál SS, Tomka P, Kovacsóczy B, Kovács L, Raskó I, Török T (2019) Ychromosome haplogroups from Hun, Avar and conquering Hungarian period nomadic people of the Carpathian Basin bioRxiv 597997. doi: https://doi.org/10.1101/597997

Niederstätter H, Rampl G, Erhart D, Pitterl F, Oberacher H, Neuhuber F, Hausner I, Gassner C, Schennach H, Berger B, Parson W (2012) Pasture names with romance and slavic roots facilitate dissection of Y chromosome variation in an exclusively German-Speaking Alpine region. PLoS One 7:e41885. https://doi.org/10.1371/ journal.pone. 0041885

Olasz J, Seidenberg V, Hummel S, Szentirmay Z, Szabados G, Melegh B, Kásler M (2018) DNA profiling of Hungarian King Béla III and other skeletal remains originating from the Royal Basilica of Székesfehérvár. Archaeol Anthropol Sci 11:1345-1357. https:// doi.org/10.1007/s12520-018-0609-7

Pamjav H, Fóthi Á, Fehér T, Fóthi E (2017) A study of the Bodrogköz population in North-Eastern Hungary by Y chromosomal haplotypes and haplogroups. Mol Gen Genomics 292:883-894. https:// doi.org/10.1007/s00438-017-1319-z

Post H, Németh E, Klima L, Flores R, Fehér T, Türk A, Székely G, Sahakyan H, Mondal M, Montinaro F, Karmin M, Saag L, Yunusbayev B, Khusnutdinova EK, Metspalu E, Villems R, Tambets K, Rootsi S (2019) Y-chromosomal connection between Hungarians and geographically distant populations of the Ural Mountain region and West Siberia. Sci Rep 9:7786. https://doi.org/ 10.1038/s41598-019-44272-6

Pauler Gy, Szilágyi S (eds) (1990) A magyar honfoglalás kútfói [Historical Sources of the Hungarian Conquest]. Magyar Tudományos Akadémia, Budapest, pp 11-89

Rębała K, Martínez-Cruz B, Tönjes A, Kovacs P, Stumvoll M, Lindner I, Büttner A, Wichmann H-E, Siváková D, Soták M, Quintana-Murci L, Szczerkowska Z, Comas D, Genographic Consortium (2013) Contemporary paternal genetic landscape of Polish and German populations: from early medieval Slavic expansion to post-World War II resettlements. Eur J Hum Genet 21:415-422. https://oi. org/10.1038/ejhg.2012.190

Révész L (1996) A karosi honfoglaláskori temetők. Régészeti adatok a Felsö-Tisza vidék X századi történetéhez [Karos cemeteries from the Hungarian Conquest period. Archaeological data from the 10th century CE Upper Tisza region]. Magyarország honfoglalás kori és Árpádkori leletei [Archaeological Remnants from the Period of the Hungarian Conquest and Arpadian Age], Miskolc

Roewer L, Krüger C, Willuweit S, Nagy M, Rodig H, Kokshunova L, Rothämel T, Kravchenko S, Jobling MA, Stoneking M, Nasidze I (2007) Y-chromosomal STR haplotypes in Kalmyk population samples. Forensic Sci Int 173:204-209. https://doi.org/10.1016/j. forsciint.2006.11.013

Róna-Tas A (1995) A magyarság korai története [Early history of the Hungarians]. Magy Tört Könyvt 9. Szeged University, Szeged

Rootsi S, Myres NM, Lin AA, Järve M, King RJ, Kutuev I, Cabrera VM, Khusnutdinova EK, Varendi K, Sahakyan H, Behar DM, Khusainova R, Balanovsky O, Balanovska E, Rudan P, 
Yepiskoposyan L, Bahmanimehr A, Farjadian S, Kushniarevich A, Herrera RJ, Grugni V, Battaglia V, Nici C, Crobu F, Karachanak S, Kashani BH, Houshmand M, Sanati MH, Toncheva D, Lisa A, Semino O, Chiaroni J, Di Cristofaro J, Villems R, Kivisild T, Underhill PA (2012) Distinguishing the co-ancestries of haplogroup $\mathrm{G}$ Y-chromosomes in the populations of Europe and the Caucasus. Eur J Hum Genet 20:1275-1282. https://doi.org/10.1038/ejhg.2012. 86

Rozhanskii IL, Klyosov AA (2012) Haplogroup R1a, its subclades and branches in Europe during the last 9,000 years. Adv Anthropol 02: 139-156. https://doi.org/10.4236/aa.2012.23017

Sarno S, Tofanelli S, De Fanti S, Quagliariello A, Bortolini E, Ferri G, Anagnostou P, Brisighelli F, Capelli C, Tagarelli G, Sineo L, Luiselli D, Boattini A, Pettener D (2016) Shared language, diverging genetic histories: high-resolution analysis of Y-chromosome variability in Calabrian and Sicilian Arbereshe. Eur J Hum Genet 24:600-606. https://doi.org/10.1038/ejhg.2015.138

Semino O, Passarino G, Quintana-Murci L, Liu A, Béres J, Czeizel A, Santachiara-Benerecetti AS (2000) MtDNA and Y chromosome polymorphisms in Hungary: inferences from the palaeolithic, neolithic and Uralic influences on the modern Hungarian gene pool. Eur J Hum Genet 8:339-346. https://doi.org/10.1038/sj.ejhg.5200468

Tambets K, Rootsi S, Kivisild T, Help H, Serk P, Loogväli E-L, Tolk H-V, Reidla M, Metspalu E, Pliss L, Balanovsky O, Pshenichnov A, Balanovska E, Gubina M, Zhadanov S, Osipova L, Damba L, Voevoda M, Kutuev I, Bermisheva M, Khusnutdinova E, Gusar V, Grechanina E, Parik J, Pennarun E, Richard C, Chaventre A, Moisan J-P, Barać L, Peričić M, Rudan P, Terzić R, Mikerezi I, Krumina A, Baumanis V, Koziel S, Rickards O, De Stefano GF, Anagnou N, Pappa KI, Michalodimitrakis E, Ferák V, Füredi S, Komel R, Beckman L, Villems R (2004) The Western and eastern roots of the Saami-the story of genetic "outliers" told by mitochondrial DNA and Y chromosomes. Am J Hum Genet 74:661-682. https:// doi.org/10.1086/383203

Tambets K, Yunusbayev B, Hudjashov G, Ilumäe A-M, Rootsi S, Honkola T, Vesakoski O, Atkinson Q, Skoglund P, Kushniarevich A, Litvinov S, Reidla M, Metspalu E, Saag L, Rantanen T, Karmin M, Parik J, Zhadanov SI, Gubina M, Damba LD, Bermisheva M, Reisberg T, Dibirova K, Evseeva I, Nelis M, Klovins J, Metspalu A, Esko T, Balanovsky O, Balanovska E, Khusnutdinova EK, Osipova LP, Voevoda M, Villems R, Kivisild T, Metspalu M (2018) Genes reveal traces of common recent demographic history for most of the Uralic-speaking populations. Genome Biol 19:139. https://doi.org/ 10.1186/s13059-018-1522-1
Tömöry G, Csányi B, Bogácsi-Szabó E, Kalmár T, Czibula Á, Csősz A, Priskin K, Mende B, Langó P, Downes CS, Raskó I (2007) Comparison of maternal lineage and biogeographic analyses of ancient and modern Hungarian populations. Am J Phys Anthropol 134:354-368. https://doi.org/10.1002/ajpa.20677

Tóth T (1981) Anthropological results concerning the ethnogenesis of Hungarians. Anthr Hung 17:5-22

Underhill PA, Poznik GD, Rootsi S, Järve M, Lin AA, Wang J, Passarelli B, Kanbar J, Myres NM, King RJ, Di Cristofaro J, Sahakyan H, Behar DM, Kushniarevich A, Šarac J, Šaric T, Rudan P, Pathak AK, Chaubey G, Grugni V, Semino O, Yepiskoposyan L, Bahmanimehr A, Farjadian S, Balanovsky O, Khusnutdinova EK, Herrera RJ, Chiaroni J, Bustamante CD, Quake SR, Kivisild T, Villems R (2015) The phylogenetic and geographic structure of Ychromosome haplogroup R1a. Eur J Hum Genet 23:124-131. https://doi.org/10.1038/ejhg.2014.50

Vásáry I (2015) A volgai magyarság: Julianus útja [the Volga Hungarians: Julian's voyage of discovery]. In: Sudár B, Petkes ZS (eds) Magyarok a honfoglalás korában [Hungarians in the time of the conquest of the homeland]. MTA BTK Magyar Östörténeti Témacsoport - Helikon, Budapest, (Magyar Östörténet I.), p 148

Venables WN, Ripley BD (2002) Modern applied statistics with S, 4th edn. Springer, New York

Zerjal T, Dashnyam B, Pandya A, Kayser M, Roewer L, Santos FR, Schiefenhövel W, Fretwell N, Jobling MA, Harihara S, Shimizu K, Semjidmaa D, Sajantila A, Salo P, Crawford MH, Ginter EK, Evgrafov OV, Tyler-Smith C (1997) Genetic relationships of Asians and Northern Europeans, revealed by Y-chromosomal DNA analysis. Am J Hum Genet 60:1174-1183

Zhao Y-B, Li H-J, Cai D-W, Li C-X, Zhang Q-C, Zhu H, Zhou H (2010) Ancient DNA from nomads in 2500-year-old archeological sites of Pengyang, China. J Hum Genet 55:215-218. https://doi.org/10. 1038/jhg.2010.8

Zhong H, Shi H, Qi X-B, Xiao C-J, Jin L, Ma RZ, Su B (2010) Global distribution of Y-chromosome haplogroup $\mathrm{C}$ reveals the prehistoric migration routes of African exodus and early settlement in East Asia. J Hum Genet 55:428-435. https://doi.org/10.1038/jhg.2010. 40

Publisher's note Springer Nature remains neutral with regard to jurisdictional claims in published maps and institutional affiliations. 